\title{
Distribution of ozone and its precursors over Bay of Bengal during winter 2009: role of meteorology
}

\author{
L. M. David, I. A. Girach, and P. R. Nair \\ Space Physics Laboratory, Vikram Sarabhai Space Centre, Trivandrum 695 022, India \\ Received: 9 May 2011 - Revised: 24 August 2011 - Accepted: 7 September 2011 - Published: 20 September 2011
}

\begin{abstract}
Measurements of ozone and $\mathrm{NO}_{2}$ were carried out in the marine environment of the Bay of Bengal (BoB) during the winter months, December 2008-January 2009, as part of the second Integrated Campaign for Aerosols, gases and Radiation Budget conducted under the Geosphere Biosphere Programme of the Indian Space Research Organization. The ozone mixing ratio was found to be high in the head and the southeast $\mathrm{BoB}$ with a mean value of $61 \pm 7 \mathrm{ppb}$ and $53 \pm 6 \mathrm{ppb}$, respectively. The mixing ratios of $\mathrm{NO}_{2}$ and $\mathrm{CO}$ were also relatively high in these regions. The spatial patterns were examined in the light of airflow patterns, air mass back trajectories and other meteorological conditions and satellite retrieved maps of tropospheric ozone, $\mathrm{NO}_{2}, \mathrm{CO}$, and fire count in and around the region. The distribution of these gases was strongly associated with the transport from the adjoining land mass. The anthropogenic activities and forest fires/biomass burning over the Indo Gangetic Plains and other East Asian regions contribute to ozone and its precursors over the BoB. Similarity in the spatial pattern suggests that their source regions could be more or less the same. Most of the diurnal patterns showed decrease of the ozone mixing ratio during noon/afternoon followed by a nighttime increase and a morning high. Over this oceanic region, photochemical production of ozone involving $\mathrm{NO}_{2}$ was not very active. Water vapour played a major role in controlling the variation of ozone. An attempt is made to simulate ozone level over the north and south BoB using the photochemical box model (NCAR-MM). The present observed features were compared with those measured during the earlier cruises conducted in different seasons.
\end{abstract}

Keywords. Atmospheric composition and structure (Pollution-urban and regional; Troposphere-composition and chemistry) - Hydrology (Transport)

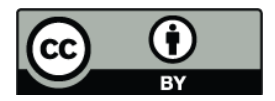

Correspondence to: P. R. Nair (prabha_nair@vssc.gov.in)

\section{Introduction}

Ozone plays a major role in the oxidation processes and radiation transfer in the atmosphere (Fishman et al., 1979; Ramanathan and Dickinson, 1979). Along with carbon dioxide, methane, water vapour and nitrous oxide, it acts as a greenhouse gas and is the third largest contributor to global warming (IPCC, 2007). The main source of ozone in the troposphere is the in situ photochemical production through the oxidation of $\mathrm{CO}, \mathrm{CH}_{4}$, non-methane hydrocarbons (NMHCs) and volatile organic compounds (VOCs), controlled and catalyzed by nitrogen oxides $\left(\mathrm{NO}_{\mathrm{x}}=\mathrm{NO}+\mathrm{NO}_{2}\right)$ (Fishman et al., 1979). Ozone chemistry can proceed in two distinct ways: when the $\mathrm{NO}_{\mathrm{x}}$ mixing ratio exceeds $\sim 50-100 \mathrm{pptv}$, ozone production dominates over destruction and in low $\mathrm{NO}_{\mathrm{x}}$ environment, net ozone destruction prevails (Crutzen, 1974). There are natural and anthropogenic sources for ozone and its precursors. The fossil fuel combustion, biomass burning, natural and human caused forest fires are significant sources of ozone precursors like $\mathrm{CO}$, VOCs and $\mathrm{NO}_{\mathrm{x}}$ in the troposphere. Once produced, it is transported to distant places along with other pollutants. Tropospheric concentrations of ozone are also influenced by downward transport from the stratosphere (Sprenger et al., 2007; Ganguly and Tzanis, 2011), and deposition to surfaces (Graedel and Crutzen, 1992). Long range transport of ozone and other pollutants also modify the tropospheric level of ozone in different regions of the world (Baldy et al., 1996; Browell et al., 1996; Jacob et al., 1999). In the marine environment, all the dominant sources of ozone and precursor gases are absent/weak and their concentrations are governed primarily by transport and photochemistry. The remote marine boundary layer, devoid of anthropogenic influence, is an ideal place to study the processes that drive the ozone photochemistry (Monks et al., 1998). The diurnal ozone cycle can reveal the role of photochemistry as an ozone source or sink (de Laat and Lelieveld, 2000). It has been proven in several remote ocean studies that the remote marine boundary layer represents a

Published by Copernicus Publications on behalf of the European Geosciences Union. 
net sink for ozone, and that photochemical destruction is the primary driving force although in some outflow regions the pollution sources can turn the balance towards ozone production (Johnson et al., 1990; Thompson et al., 1993; Kley et al., 1996; Lal and Lawrence, 2001). However, long term measurements of tropospheric ozone in the marine/oceanic environments are scarce. Available information on ozone in the marine atmosphere is based on campaign mode observations conducted over various oceanic regions (Johnson et al., 1990; Thompson et al., 1993; Lelieveld et al., 2004).

This paper presents the observational results of the shipbased measurement of ozone and $\mathrm{NO}_{\mathrm{x}}$ in the marine boundary layer of the Bay of Bengal $(\mathrm{BoB})$ carried out as part of the second Integrated Campaign for Aerosols, gases and Radiation Budget (ICARB) conducted under the Geosphere Biosphere Programme of the Indian Space Research Organization (ISRO-GBP) during the winter period, from 27 December 2008 to 30 January 2009. Even though limited measurements of ozone and precursors are available from the BoB region (Lawrence and Lelieveld, 2010, and references therein), the present study is unique in the context of the larger spatial coverage over the $\mathrm{BoB}$ compared to the previous measurements. Moreover, this was the first time that direct measurements of $\mathrm{NO}_{2}$ were carried out over this region. The earlier studies on ozone were conducted during the post-monsoon (September-October) and pre-monsoon/summer (FebruaryApril) months (Lal et al., 2006, 2007; Sahu et al., 2006). In view of this, the present study forms an extension to the above and brings out the seasonal variability. The role of continental outflow/transport in establishing the spatial pattern of ozone and $\mathrm{NO}_{\mathrm{x}}$ over the $\mathrm{BoB}$ was investigated in detail. In addition to this, the satellite derived tropospheric column ozone and $\mathrm{NO}_{2}$ over the $\mathrm{BoB}$ and the adjoining region were also examined along with the in situ measured nearsurface mixing ratios of these species to understand their relative contributions.

\section{Experimental techniques and data}

Continuous measurement of near-surface ozone was made onboard the ship using a UV photometric ozone analyzer (Model $\mathrm{O}_{3} 42 \mathrm{M}$ of Environment S. A., France). It works on the principle of absorption of UV radiation at $253.7 \mathrm{~nm}$ by ozone in the ambient air. The lower detection limit of the instrument is $1.0 \mathrm{ppb}$ with a response time of $10 \mathrm{~s}$ and measurement precision of $\sim 1 \mathrm{ppb}$. Zero noise of the instrument is $0.5 \mathrm{ppb}$, linearity $\pm 1 \%$ (full scale) and zero drift $<1 \mathrm{ppb}$. Simultaneous measurement of nitrogen oxides $\left(\mathrm{NO}, \mathrm{NO}_{2}\right.$ and $\mathrm{NO}_{\mathrm{x}}$ ) were carried out with a chemiluminescence low level $\mathrm{NO}_{\mathrm{x}}$ analyzer (Model 42i of Thermo Electron Corporation, USA). It works on the principle of chemiluminescence effect produced by the oxidation of NO by ozone molecules, which peaks at $630 \mathrm{~nm}$ radiation. $\mathrm{NO}_{2}$ was measured by converting it into NO using the thermal conversion method (molybde- num convertor). The instrument has a lower detection limit of $50 \mathrm{ppt}$ with a response time of $60 \mathrm{~s}$ and measurement precision of $\sim 50 \mathrm{ppt}$. Zero noise of the instrument is $25 \mathrm{ppt}$ rms and it has a linearity and span drift of $\pm 1 \%$ (full scale). The calibration of the instruments was carried out periodically using appropriate calibration standards traceable to NIST and multi-channel calibrator before, during and after the cruise. The calibration constants did not show significant variation. The data averaged at $5 \mathrm{~min}$ interval was used for the study. Air sample is drawn in from a height of about $10 \mathrm{~m}$ from the sea surface, through a teflon tube. The data is excluded when measurements were done in harbours and their nearest surroundings and whenever the ship was stationary and the wind direction was adverse. Due to these factors about $5 \%$ of data have been excluded from the analysis. In addition to this, $\mathrm{CO}$ measurements were carried out onboard the ship using CO analyzer (Model CO12 Module of Environment S. A., France). The observational results of this study have been already published by Asatar and Nair (2010). In the present study, $\mathrm{CO}$ data is also used along with ozone and $\mathrm{NO}_{2}$ for comparing their spatial changes.

Surface level meteorological parameters namely: air temperature $(T)$, relative humidity $(\mathrm{RH})$, pressure $(P)$, wind speed (WS) and wind direction (WD) at a height of $10 \mathrm{~m}$ above sea level were continuously monitored and recorded at $10 \mathrm{~min}$ interval along the cruise track. The ship speed and ship-head angle was available through global positioning system measurement and were used to correct the boombased wind speed and direction measurement as reported by Smith et al. (1999).

In addition, the spatial pattern of the in situ measured near-surface ozone and $\mathrm{NO}_{2}$ has been compared with the satellite-based measurement of tropospheric column ozone and $\mathrm{NO}_{2}$. OMI (Ozone Monitoring Instrument) aboard AURA measures the total column ozone and MLS (Microwave Limb Sounder) provides the stratospheric column ozone determined by a standard method of pressure integration of ozone volume mixing ratio from $0.46-215 \mathrm{hPa}$ (Ziemke et al., 2006). Tropospheric column ozone is determined using the "residual method" that involves subtracting measurement of MLS stratospheric column ozone from OMI total column ozone. The mean tropospheric volume mixing ratio (ppbv) is calculated from the equation: 1.27 . $\mathrm{TCO} /\left(P_{\text {surface }}-P_{\text {tropopause }}\right)$, where TCO is in DU (Dobson Unit) and pressure $(P)$ in $\mathrm{hPa}$. The data is available with a resolution of $1^{\circ} \times 1.25^{\circ}$ (latitude $\times$ longitude) at the ftp site (ftp://jwocky.gsfc.nasa.gov/pub/ccd/data_monthly_new). The precision uncertainty for the derived gridded ozone is $5 \mathrm{DU}$ (the mean tropospheric mixing ratio is $7 \mathrm{ppbv}$ ) with mean offset of 2 DU (OMI/MLS) (Ziemke et al., 2009). OMI also gives the tropospheric $\mathrm{NO}_{2}$ column available daily with a resolution of $0.25^{\circ} \times 0.25^{\circ}$ (level 3, gridded) from the website (http://avdc.gsfc.nasa.gov/) with an uncertainty of $0.1 \times 10^{15}$ molecules $\mathrm{cm}^{-2}$. The tropospheric column $\mathrm{NO}_{2}$ is found to be underestimated by $15-30 \%$ (Celarier et al., 


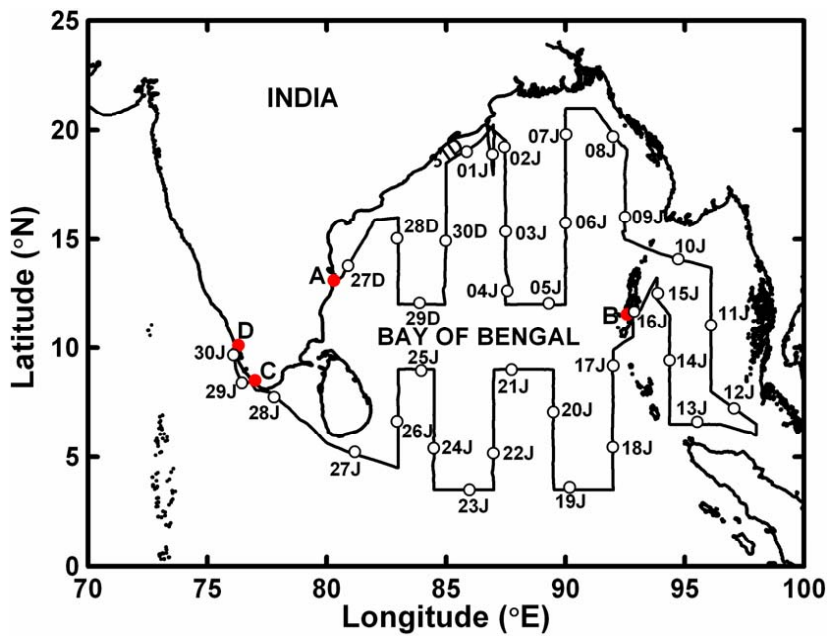

Fig. 1. Cruise track of the oceanic research vessel (ORV) Sagar Kanya (Cruise No. SK254).

2008). The column CO is retrieved from the MOPITT (Measurement of Pollution In The Troposphere), which uses the gas correlation radiometry (Kar et al., 2008) and available from the website http://eosweb.larc.nasa.gov/ over a grid size of $1^{\circ} \times 1^{\circ}$. The fire counts is detected from the brightness temperature from the MODerate resolution Imaging Spectrometer (MODIS) on board Aqua at $4 \mu \mathrm{m}$ and $11 \mu \mathrm{m}$ channel over a grid size of $1^{\circ} \times 1^{\circ}$ (http://disc.sci.gsfc.nasa.gov/ neespi/data-holdings/myd14cm1.shtml) (Giglio et al., 2003).

\section{The cruise track and meteorology}

Figure 1 shows the cruise track of the oceanic research vessel (ORV) Sagar Kanya (Cruise No. SK254) during the campaign. The ship sailed off the Chennai port (marked as A) on 27 December 2008 toward north along the coastal region. On reaching the location $16^{\circ} \mathrm{N}, 82^{\circ} \mathrm{E}$ it moved eastward up to $83^{\circ} \mathrm{E}$ and from there it deviated toward south moving along the longitude $83^{\circ} \mathrm{E}$ doing a latitudinal scan up to $12^{\circ} \mathrm{N}$. Thereafter the ship made several longitudinal and latitudinal scans in the mid, eastern and south eastern BoB reaching Port Blair (marked as B) on 16 January 2009. It moved southward along $92^{\circ} \mathrm{E}$ longitude up to $3.5^{\circ} \mathrm{S}$ then moved westward along this latitude and turned northward along $89.5^{\circ} \mathrm{E}$ to $9^{\circ} \mathrm{N}$. It made few more longitudinal scans over the southern BoB and thereafter moving close by Sri Lanka reached Cochin (marked as C) on 30 January 2009. The dates are shown next to the circles written with three characters, the first two denotes the date followed by the month (D and J for December and January, respectively), mark the mean position of the ship on each day. The cruise track was planned and coordinated to cover the surface observations in the coastal, open ocean, eastern, south eastern and southern part of BoB. It had an extensive latitudinal and
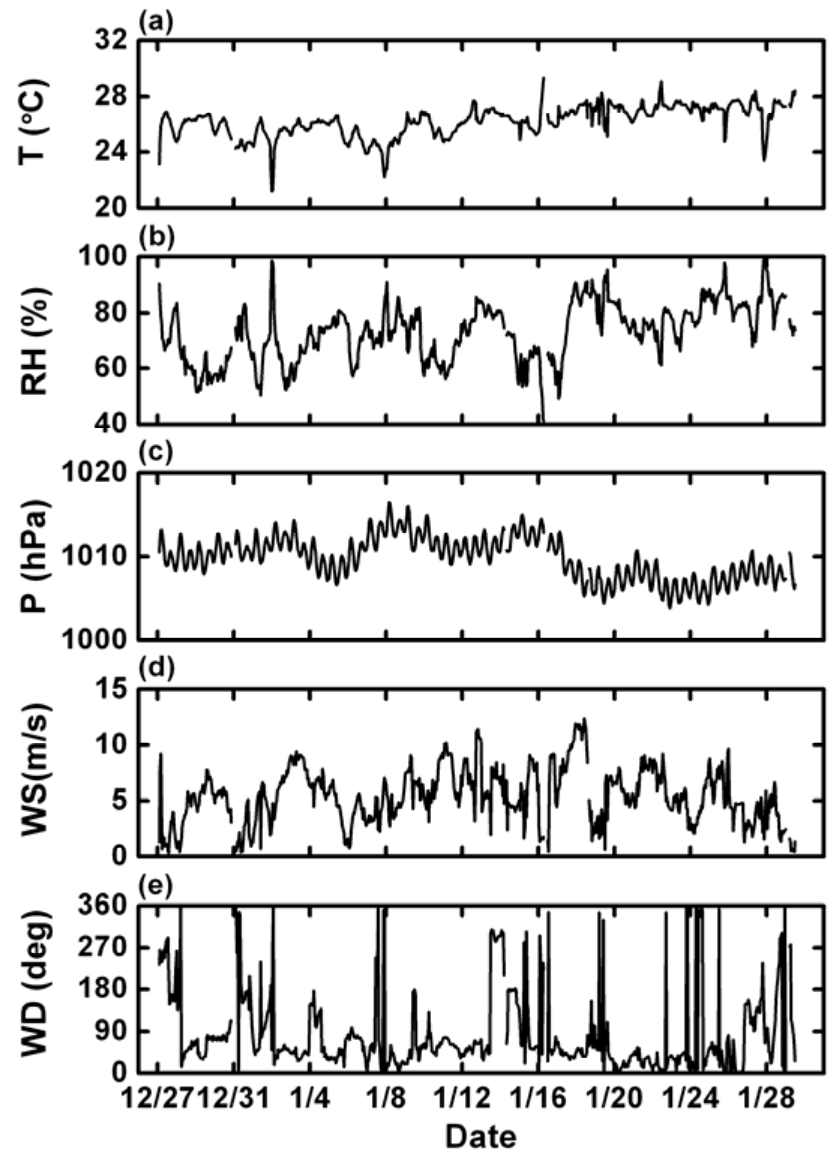

Fig. 2. Variation of (a) temperature $(T)$; (b) relative humidity $(\mathrm{RH})$; (c) pressure $(P)$; (d) wind speed (WS) and (e) wind direction (WD) during the cruise period on day-to-day basis.

longitudinal coverage from $3.5^{\circ} \mathrm{N}-21^{\circ} \mathrm{N}$ and $76^{\circ} \mathrm{E}-98^{\circ} \mathrm{E}$, respectively.

Figure 2a to e shows the day-to-day variation of (a) $T$, (b) RH, (c) $P$, (d) WS and (e) WD observed during the cruise period. The daily mean air temperature varied $\sim 22-29^{\circ} \mathrm{C}$ and RH being in the range $50-98 \%$. The wind speed varied from a low value of $\sim 1 \mathrm{~m} \mathrm{~s}^{-1}$ to a maximum of $\sim 12 \mathrm{~m} \mathrm{~s}^{-1}$ with a mean wind speed of $4 \mathrm{~m} \mathrm{~s}^{-1}$ during the campaign period. The airflow over the northern BoB region was mostly northwesterly/northeasterly (from the land mass) and easterly in the southeast BoB such that measurements were made on the downwind side. The ship encountered a region of high temperature and low pressure during 16-29 January while it was traversing the southern $\mathrm{BoB}$.

\section{Results and discussions}

\subsection{Spatial variation of ozone and $\mathrm{NO}_{2}$}

The variation of ozone and $\mathrm{NO}_{2}$ along the cruise track is shown in Fig. 3a and b, respectively. From the figure, it 

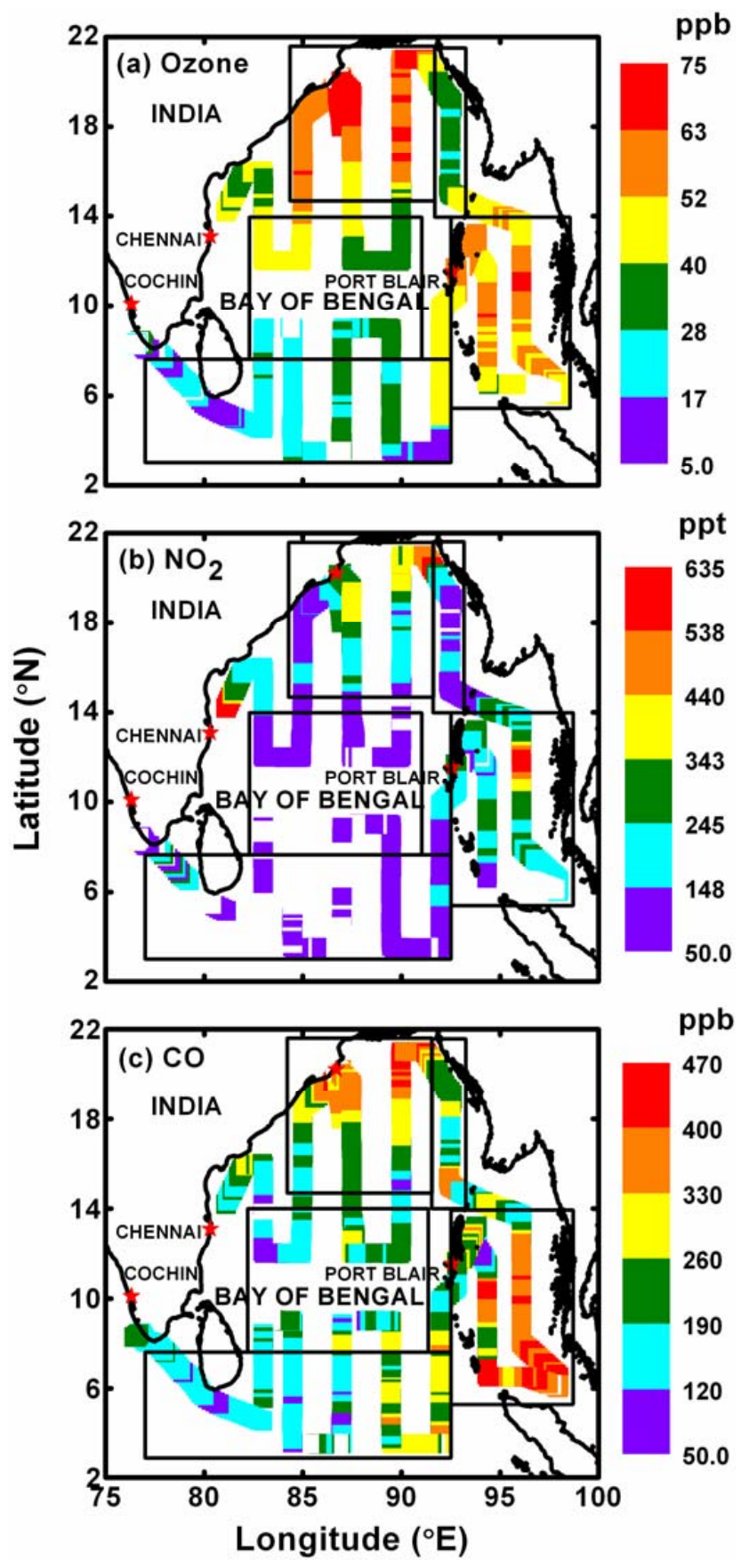

Fig. 3. Variation of (a) surface ozone; (b) $\mathrm{NO}_{2}$ and (c) $\mathrm{CO}$ along the cruise track.

is evident that the ozone mixing ratio was high over the northern/head $\mathrm{BoB}\left(15^{\circ}-21^{\circ} \mathrm{N}\right.$ and $\left.85^{\circ}-91.5^{\circ} \mathrm{E}\right)$ and the southeast $\mathrm{BoB}\left(6^{\circ}-14^{\circ} \mathrm{N}\right.$ and $\left.92.5^{\circ}-98^{\circ} \mathrm{E}\right)$ and low over the south/southwestern $\mathrm{BoB}$ regions. $\mathrm{NO}_{2}$-a precursor of ozoneshowed more or less similar pattern, with high over the head $\mathrm{BoB}$ and the northeast $\mathrm{BoB}\left(20^{\circ}-21^{\circ} \mathrm{N}\right.$ and $\left.91.5^{\circ} \mathrm{E}\right)$. Unlike ozone, $\mathrm{NO}_{2}$ showed very low mixing ratio over a wide region covering the mid and the southern $\mathrm{BoB}$. In fact, the $\mathrm{NO}_{2}$ val-

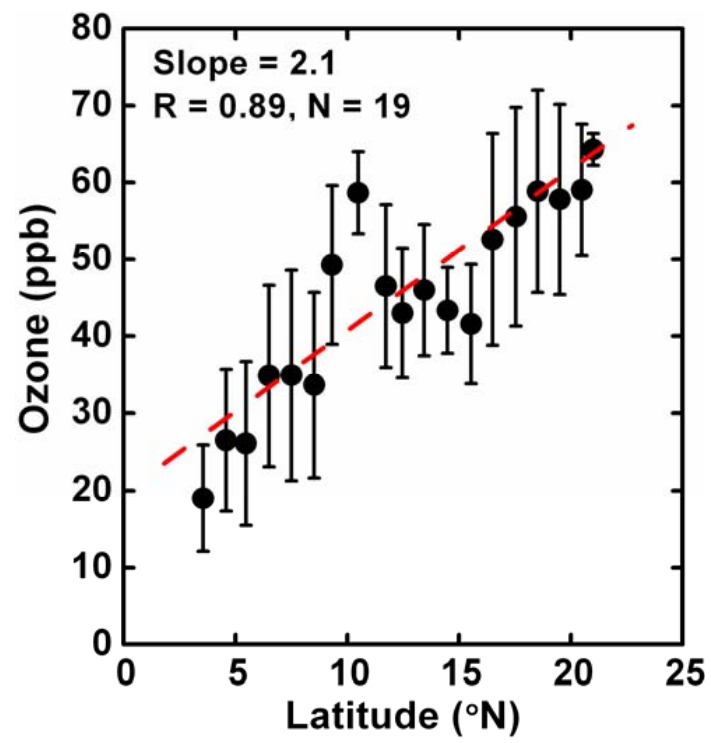

Fig. 4. Latitudinal gradient of the ozone mixing ratio.

ues were below the detection limit of the instrument at many locations in the southern BoB (as seen by the blank regions). The spatial pattern of $\mathrm{CO}$-another precursor for the ozone formation-is also shown in Fig. 3c, which is broadly similar to that of ozone. The details on the spatial variation of $\mathrm{CO}$ along with the role of transport in establishing the pattern has been already published (Asatar and Nair, 2010). The main focus of this paper is on the spatial variation of near-surface ozone and $\mathrm{NO}_{2}$ and their inter-dependence. Similarity in the spatial patterns of ozone and its precursor points out that the source regions and transport mechanisms may be the same, but their relative contributions may vary.

Based on the spatial pattern of ozone and $\mathrm{NO}_{2}$ (as seen in Fig. 3a and $b$ ), the data is grouped into five regions having distinct patterns (marked with boxes in Fig. 3). Group 1 represents the head $\mathrm{BoB}\left(15^{\circ}-21^{\circ} \mathrm{N}\right.$ and $\left.85^{\circ}-91.5^{\circ} \mathrm{E}\right)$, group 2 the northeast (NE) $\mathrm{BoB}\left(14^{\circ}-21^{\circ} \mathrm{N}\right.$ and $\left.91.5^{\circ}-92.5^{\circ} \mathrm{E}\right)$, group 3 the southeast (SE) $\mathrm{BoB}\left(6^{\circ}-14^{\circ} \mathrm{N}\right.$ and $\left.92.5^{\circ}-98^{\circ} \mathrm{E}\right)$, group 4 the mid- $\mathrm{BoB}\left(8-13.5^{\circ} \mathrm{N}\right.$ and $\left.83^{\circ}-91^{\circ} \mathrm{E}\right)$ and group 5 the southern (S) BoB/Indian Ocean $\left(3.5^{\circ}-8^{\circ} \mathrm{N}\right.$ and $77^{\circ}-$ $91.8^{\circ} \mathrm{E}$ ). The mean mixing ratio of surface ozone and $\mathrm{NO}_{2}$ in these regions is given in Table 1. Both these species show similar spatial variation except that $\mathrm{NO}_{2}$ remained more or less steady over the mid and southern BoB, while the ozone mixing ratio was high over the mid $\mathrm{BoB}$ and decreased toward the south. Highest ozone mixing ratio was observed over the head BoB with slightly lower values over the southeast $\mathrm{BoB}$. On the other hand, $\mathrm{NO}_{2}$ is found to be comparable over the head $\mathrm{BoB}$ and southeast $\mathrm{BoB}$. The $\mathrm{NO}_{2}$ measured over the $\mathrm{BoB}$ were higher than the values over the north Atlantic and western and tropical Pacific (Carsey et al., 1997; Singh et al., 1996a and b). Most often $\mathrm{O}_{3} / \mathrm{NO}_{2}$ ratio is used as an indicator of ozone sensitivity to $\mathrm{NO}_{2}$. This ratio 

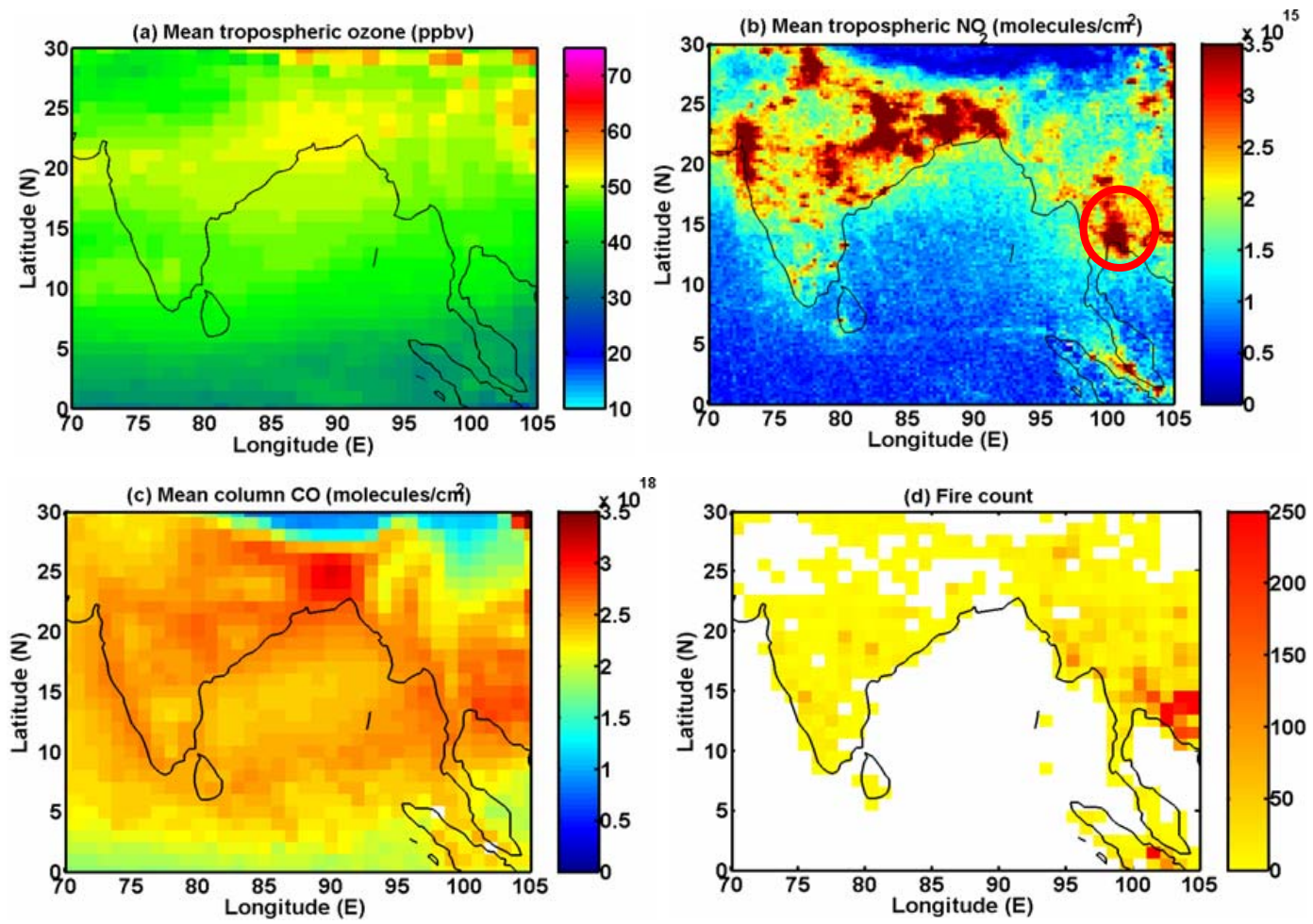

Fig. 5. Variation of tropospheric column (a) ozone and (b) $\mathrm{NO}_{2}$; (c) column $\mathrm{CO}$ and (d) fire count.

is of importance under polluted environments or over land where $\mathrm{NO}_{\mathrm{x}}$ initiated photochemical production of ozone is predominant. Extremely low values of the ratio occur for large point sources or close to plumes. In the present study, which is confined to the marine environment, the $\mathrm{O}_{3} / \mathrm{NO}_{2}$ ratios are extremely high (Table 1), which indicate weakening of the photochemical production of ozone, termination of $\mathrm{NO}_{\mathrm{x}}$, aging of ozone and precursors, etc. (Tonnesen and Dennis, 2000). Similar ratios were reported from the marine environment of Pacific (Singh et al., 1996a, b).

\subsection{Latitudinal gradient}

The vast latitudinal coverage from $3.5^{\circ} \mathrm{N}-21^{\circ} \mathrm{N}\left(\sim 17.5^{\circ}\right)$ of the ship in 34 days is used to examine the latitudinal gradient in ozone. The ozone mixing ratio measured during the cruise was grouped into $1^{\circ}$ latitude bin (irrespective of the longitude), averaged and plotted in Fig. 4 along with the respective standard deviation. The ozone shows a steep gradient from northern to southern latitudes with high mixing ratios in the northern latitudes. The overall linear gradient deduced by the least square method is $2.1 \pm 0.3 \mathrm{ppb}^{\circ-1}$ with a correlation coefficient of 0.89 . The gradient observed in the present campaign is higher compared to those reported (1.3 to $1.5 \mathrm{ppb}^{\circ-1}$ ) during the post-winter (Nair et al., 2011) and post-monsoon periods (Sahu et al., 2006). Still higher gradients were observed over the Arabian Sea and the In-
Table 1. The mean mixing ratio of surface ozone and $\mathrm{NO}_{2}$ over the different regions of Bay of Bengal.

\begin{tabular}{lccc}
\hline \multirow{2}{*}{ Region } & \multicolumn{3}{c}{ Surface } \\
\cline { 2 - 4 } & Ozone $(\mathrm{ppb})$ & $\mathrm{NO}_{2}(\mathrm{ppt})$ & Ozone/NO \\
\hline Head BoB & $61 \pm 7$ & $240 \pm 104$ & 254 \\
Northeast BoB & $36 \pm 7$ & $170 \pm 102$ & 212 \\
Southeast BoB & $53 \pm 6$ & $261 \pm 107$ & 203 \\
Mid-BoB & $36 \pm 8$ & $79 \pm 21$ & 456 \\
South BoB & $24 \pm 7$ & $95 \pm 51$ & 253 \\
\hline
\end{tabular}

dian Ocean during INDOEX 1998 (1.8 to $3.3 \mathrm{ppb}^{\circ-1}$ ) and INDOEX 1999 (-4.5 to $7.5 \mathrm{ppb}^{\circ-1}$ ) (Chand et al., 2003).

\subsection{Spatial pattern of satellite retrieved tropospheric column $\mathrm{O}_{3}$ and $\mathrm{NO}_{2}$ over the cruise region}

In order to understand whether the spatial pattern of surface level ozone has any bearing on the tropospheric column, the satellite-based measurement of tropospheric column ozone was examined. In Fig. 5a, the mean tropospheric volume mixing ratio of ozone for the month of January 2009 (cruise period) is shown. The mixing ratio of ozone varied in the range 35-55 ppbv with high values over the head BoB region and showed a gradual decrease toward the southern latitudes. 
(a) Wind $(27 / 12 / 2008$ to $07 / 01 / 2009)$

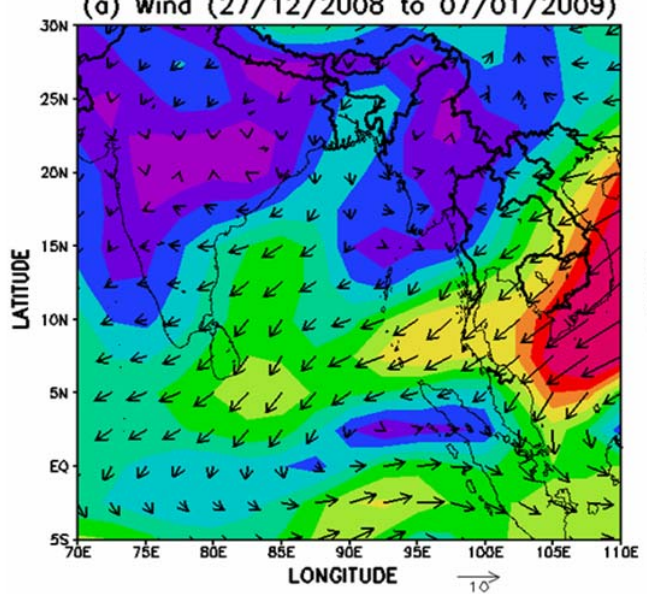

(c) Wind $(11 / 01 / 2009$ to $18 / 01 / 2009)$

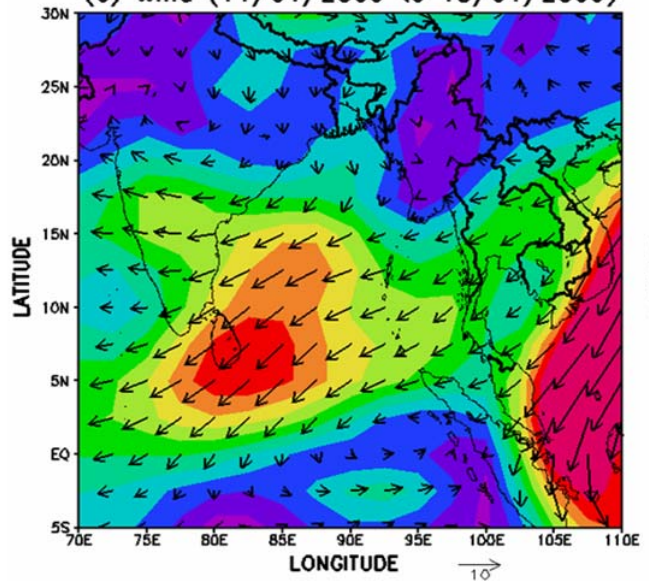

(b) Wind $(08 / 01 / 2009$ to $10 / 01 / 2009)$

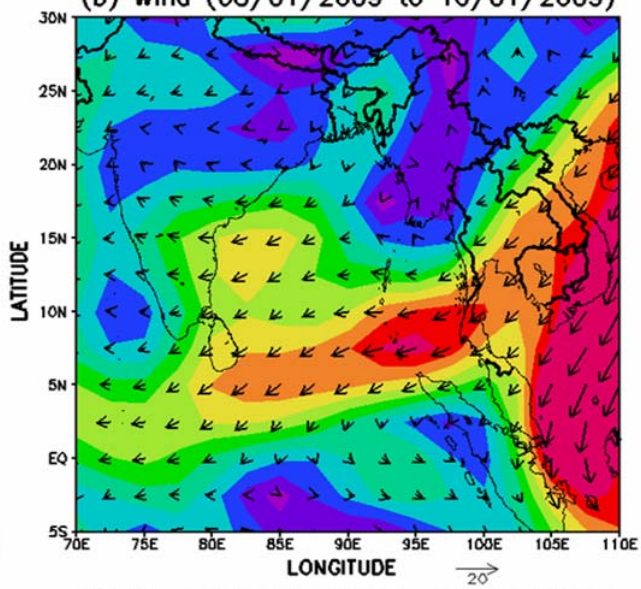

(d) Wind $(19 / 01 / 2009$ to $29 / 01 / 2009)$

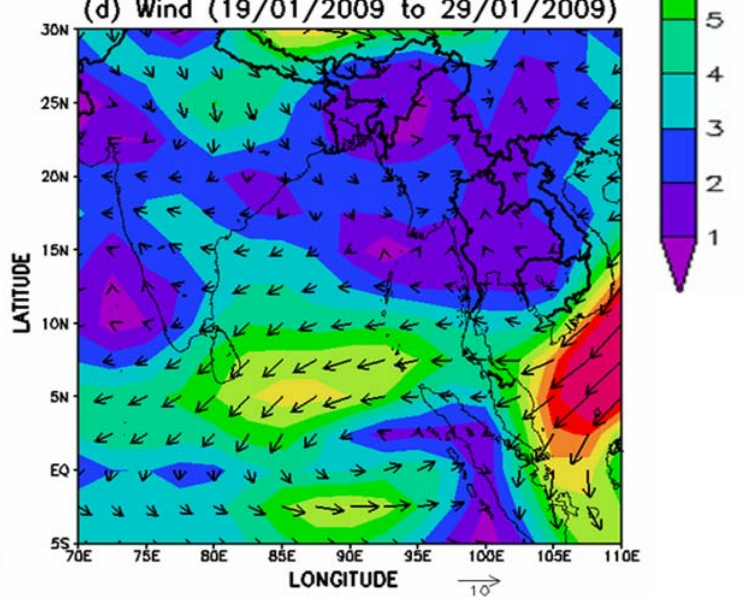

Fig. 6. Mean airflow pattern at $925 \mathrm{hPa}$ over the ocean and surrounding continent obtained from NCEP/NCAR reanalysis. The colour scale represents the magnitude of the wind speed.

With a view to understanding the correlation between ozone and $\mathrm{NO}_{2}$, the day-to-day maps of tropospheric column $\mathrm{NO}_{2}$ during the cruise were also examined (figures for individual days are not shown) and in Fig. 5b is shown the tropospheric column $\mathrm{NO}_{2}$ averaged for the cruise period. Tropospheric $\mathrm{NO}_{2}$ was high close to the coastal regions, northern $\mathrm{BoB}$ and also over the southeast BoB. Also, hot spots of tropospheric $\mathrm{NO}_{2}$, was seen over land in the eastern parts of India, Indo Gangetic Plains (IGP), and east/southeast Asian regions. It may be noted that the IGP region is thickly populated encompassing many major industrialized urban centres. Also, numerous coal mines, coal-based thermal power plants and other heavy industries are spread over the eastern IGP region (Prasad et al., 2006). During winter the meteorological conditions are conducive for confinement of pollutant gases to lower altitudes which gets transported to $\mathrm{BoB}$ as discussed in Sect. 4.4. However, the short lifetime of $\mathrm{NO}_{2}(\sim 1-2$ days $)$ restricts the advection over to the remote oceanic region as it gets converted into nitric acid (McConnell and McElroy, 1973; Platt et al., 1984).

\subsection{Variation of near-surface ozone and $\mathrm{NO}_{2}$ - role of transport}

The major source of ozone over the oceanic region is via transport of ozone and/or precursors from the adjacent continental region where significant amount of anthropogenic activities take place. The spatial distribution of tropospheric ozone and $\mathrm{NO}_{2}$ (Fig. 5a and b) indicates pollution sources spread over the Indian subcontinent. Moreover, distribution of $\mathrm{CO}$ is a tracer for anthropogenic activities and fire counts indicate biomass burning, which produces precursors for ozone. Figure $5 \mathrm{c}$ shows the spatial pattern of atmospheric column CO and Fig. 5d shows the fire counts detected during January 2009. While the fire count over IGP is $<100$, it rises to $\sim 150-250$ over the east/southeast Asian region. Since these pollutants can reach the BoB under favourable wind condition, the mean airflow patterns (at $925 \mathrm{hPa}$ ) over the ocean and surrounding continent obtained from the $\mathrm{Na}-$ tional Centers for Environmental Prediction/National Center for Atmospheric Research reanalysis (http://www.esrl.noaa. 

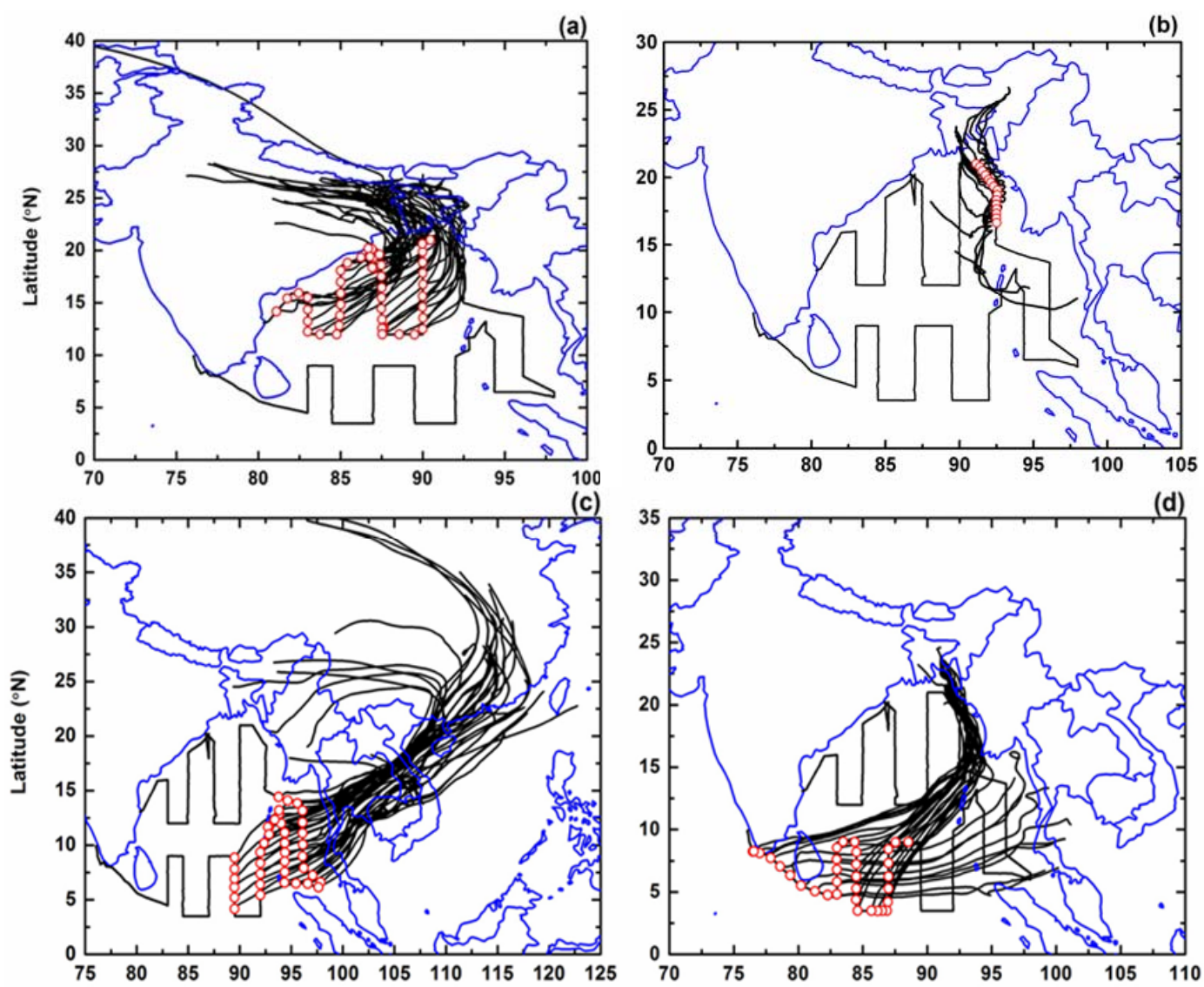

(e)
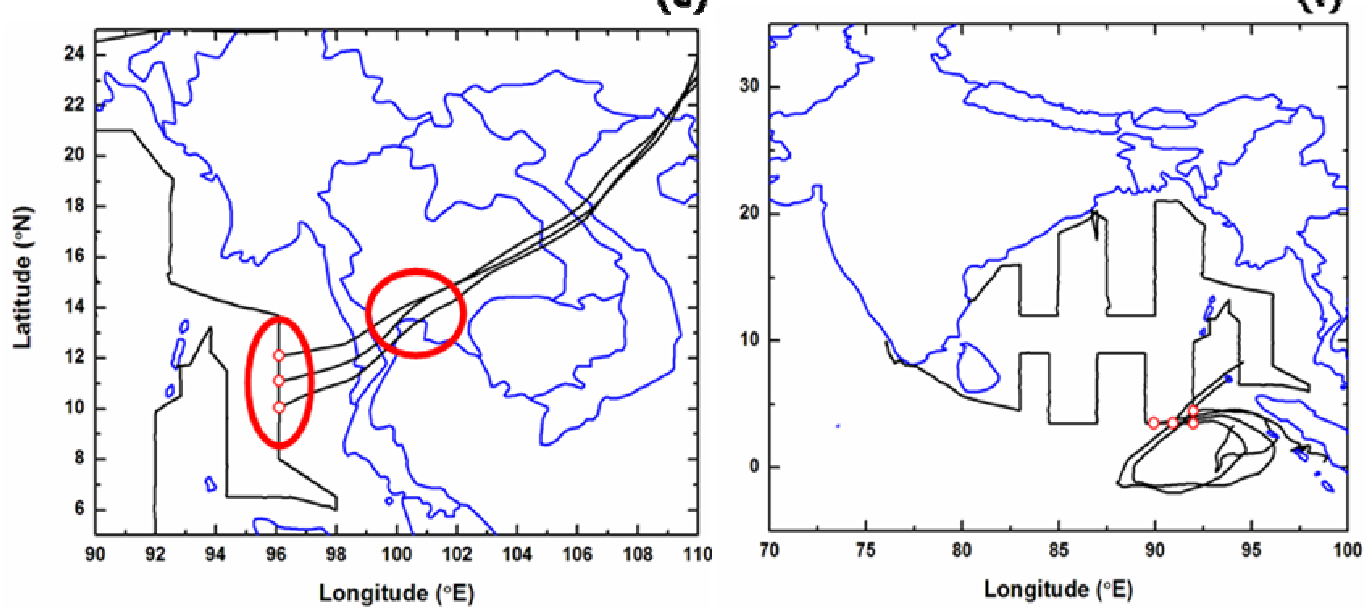

Fig. 7. Five-day air mass back trajectories reaching the ship at $100 \mathrm{~m}$ obtained from the HySPLIT model for each day and grouped in terms of the observed changes in ozone levels.

gov/psd/data/gridded/reanalysis/) were examined on day-today basis along with the air mass back trajectories. Figure 6a to $\mathrm{d}$ shows the mean airflow pattern for 27 December 2008 to 7 January 2009 (ship near to the coast and the head BoB region), 8-10 January (when ship was in the NE BoB), 1118 January (ship was traversing in the southeast $\mathrm{BoB}$ ) and 19-29 January (when ship was in the mid and the southern
$\mathrm{BoB})$, respectively. When the ship was moving north along the coastal and the head BoB region, the airflow was from the northern part of the Indian subcontinent and the IGP (Fig. 6a) with low speed. In the $\mathrm{NE} \mathrm{BoB}$, the winds were northerly (Fig. 6b) and there was a region of cyclonic flow centred at $20^{\circ} \mathrm{N}, 97^{\circ} \mathrm{E}$. In the southeast $\mathrm{BoB}$, the winds were stronger (wind speed $\sim 10 \mathrm{~m} \mathrm{~s}^{-1}$ ) and easterly/northeasterly (Fig. 6c) 

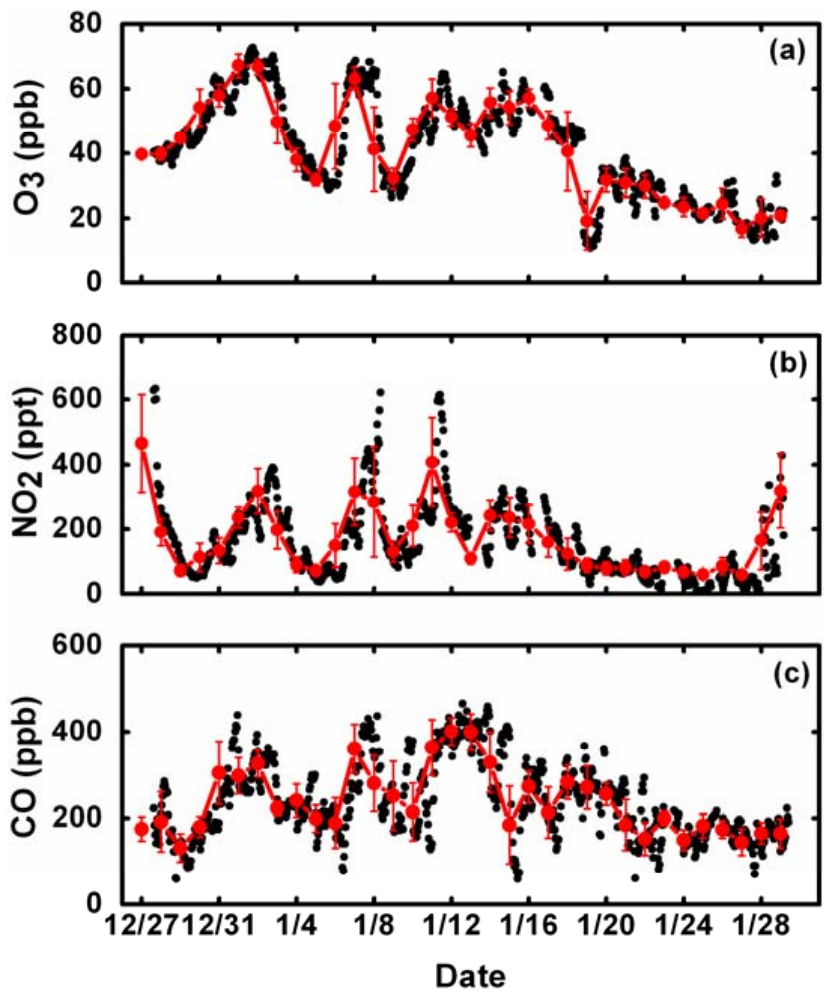

Fig. 8. Hourly (black) and daily (red) variation of (a) ozone, (b) $\mathrm{NO}_{2}$ and (c) $\mathrm{CO}$ over the $\mathrm{BoB}$.

bringing the polluted continental air from the SE Asian region. In the mid and the southern $\mathrm{BoB}$, the airflow was mostly easterly with relatively low wind speed (Fig. 6d) and also there was a mixing of continental air with the pristine air from the ocean.

The five-day air mass back trajectories reaching the ship at $100 \mathrm{~m}$ (within the boundary layer) at 00:00, 06:00, 12:00 and 18:00 UT were obtained by running the Hybrid Single-Particle Lagrangian Integrated Trajectory (HySPLIT) model (Draxler and Rolph, 2003, http://ready.arl.noaa.gov/ HYSPLIT.php) for each day. Based on the observed spatial features in surface ozone/ $\mathrm{NO}_{2}$, these trajectories were grouped and shown in Fig. 7a to d. When the ship was moving in the head $\mathrm{BoB}$, the ozone and $\mathrm{NO}_{2}$ mixing ratios were high and the air mass back trajectories (Fig. 7a) reaching this region originated from the northwest land mass and traversed the eastern part of IGP. In these regions, the mixing ratio of tropospheric ozone and $\mathrm{NO}_{2}$ values were high lying in the range $50-55 \mathrm{ppbv}$ and $4-7 \times 10^{15}$ molecules $\mathrm{cm}^{-2}$, respectively (Fig. 5a and b). In the north eastern part of the BoB, the ozone mixing ratio showed relatively low values compared to the head and the southeast BoB. The air mass back trajectories reaching this part originated from the nearby regions (mostly oceanic) as seen from Fig. 7b. Majority of these back trajectories originated and travelled through low altitudes $(<1000 \mathrm{~m})$. The origin of air mass back trajecto- ries reaching southeast $\mathrm{BoB}$ (where ozone and $\mathrm{NO}_{2}$ were high) traced back to the SE Asian countries (Fig. 7c). Figure $5 \mathrm{a}$ and $\mathrm{b}$ shows that these are regions of high ozone and $\mathrm{NO}_{2}$ (reaching $60 \mathrm{ppb}$ and $3-6 \times 10^{15}$ molecules $\mathrm{cm}^{-2}$, respectively). Also it can be seen that these are regions of high $\mathrm{CO}$ (Fig. 5c). Over the south/south western BoB, where mixing ratios of surface ozone and $\mathrm{NO}_{2}$ were found to be low, the back trajectories originated from the coastal regions or regions where tropospheric $\mathrm{NO}_{2}$ and ozone were moderately high. The longer path traversed by the air mass (Fig. 7d) over the marine environment, rich in water vapour, which is a source of $\mathrm{OH}$ radical, could have resulted in the destruction of ozone and precursors. There is also a possibility of updrafts and downdrafts that can cause changes in the mixing ratio of ozone and precursors at the surface level. In this context, it may be noted that this was also a region of low surface pressure (Fig. 2). It is also worth noting that, at most of the locations during the cruise, the back trajectories were confined to altitudes $<2000 \mathrm{~m}$ facilitating transport of pollutant gases trapped in the lower altitudes of the atmosphere.

In the spatial pattern of ozone and $\mathrm{NO}_{2}$, an isolated hotspot can be seen over the south eastern BoB (around $11^{\circ}-12^{\circ} \mathrm{N}$, $96^{\circ} \mathrm{E}$ in Fig. 3b, red coloured) unlike in $\mathrm{CO}$ or ozone which showed high along the entire track/region (Fig. 3a and c). Figure 7e shows the back trajectories reaching this location. It is to be noted that the trajectories passed through the high fire count regions seen from Fig. $5 \mathrm{~d}$ bringing in $\mathrm{NO}_{2}$ /ozone. It is also seen that these high fire count regions showed high $\mathrm{NO}_{2}$ (marked by a red circle in Fig. 5b). The hotspot and the high fire count regions are marked in Fig. 7e. Another striking feature in the spatial pattern of ozone was the prominent low seen around $3^{\circ}-4^{\circ} \mathrm{N}, 90^{\circ}-92^{\circ} \mathrm{E}$. Figure $7 \mathrm{f}$ shows this region along with the back trajectories reaching this location, which had their origin in and around the oceanic environment following a different path. Moreover, the relative humidity was also high $(>95 \%)$ in this region as can be seen from Fig. 2b. Few rain events occurred around the cruise region during that period as seen from the rainfall data from TRMM (Tropical Rainfall Measuring Mission) which would have contributed to the elevated level of RH.

More quantitative assessment of changes in ozone and precursor gases- $\mathrm{NO}_{2}$ and $\mathrm{CO}$ was carried out by examining their respective mixing ratios recorded along the cruise track on hourly basis. Figure $8 \mathrm{a}, \mathrm{b}$ and $\mathrm{c}$ shows the hourly variation of ozone, $\mathrm{NO}_{2}$ and $\mathrm{CO}$, respectively over the $\mathrm{BoB}$ along with the daily averaged values (shown by solid line). Since the cruise had coverage of $\sim 420 \mathrm{~km} \mathrm{day}^{-1}$, the daily averages represent the mean value along that distance. All the three species showed more or less similar variations up to 12 January, while ship was traversing the coastal regions of northern BoB, the head BoB and the south eastern BoB, indicative of similar sources/source regions for these species. The high in ozone observed over the south eastern BoB is more extended compared to $\mathrm{NO}_{2}$ and $\mathrm{CO}$. All these gases showed low mixing ratios over the southern BoB (toward 
second half of January). The entire data of $\mathrm{O}_{3}$ and $\mathrm{NO}_{2}$ were used to generate a scatter plot between the two as shown in Fig. 9a. Ozone shows increase up to $0.34 \mathrm{ppb}$ of $\mathrm{NO}_{2}$ beyond which it remains insensitive. The straight lines represent the best-fit obtained through linear regression analysis (excluding data corresponding to $\mathrm{NO}_{2} \geq 0.34 \mathrm{ppb}$ ). In Fig. $9 \mathrm{~b}$ and $\mathrm{c}$ are shown the scatter plot between ozone versus $\mathrm{CO}$ and $\mathrm{CO}$ versus $\mathrm{NO}_{2}$, respectively (daily mean values) along with the regression fitted straight lines. It is seen that the ozone mixing ratio is positively correlated with $\mathrm{NO}_{2}$ and $\mathrm{CO}$ with the correlation coefficient as 0.71 and 0.72 , respectively. $\mathrm{CO}$ and $\mathrm{NO}_{2}$ also showed a positive correlation with the correlation coefficient as 0.72 . The positive correlation between $\mathrm{O}_{3}$ and its precursors is due to the fact that they were emitted from the same sources/region as revealed by the air mass back trajectories (Fig. 7). Biomass burning/forest fires and fossil fuel combustion associated with the anthropogenic activities form the two major sources of these gases. The spatial variation of ozone, $\mathrm{NO}_{2}$ and $\mathrm{CO}$ (Fig. 3a, b and c, respectively) and the fire count data (Fig. 5d) in and around BoB reflect this.

\subsection{Diurnal variation in ozone}

The diurnal variation of ozone observed over the oceanic environment is different from that observed over land as discussed in the earlier studies (Johnson et al., 1990; Rhoads et al., 1997; Bhugwant et al., 2001). Over the land, ozone shows an increase few hours after sunrise reaching peak values before noon and starts decreasing in the afternoon reaching low values at night (Lal et al., 2000; David and Nair, 2011). The nature of diurnal variation can provide information on the role of photochemistry, mesoscale transport and the effect of meteorological parameters viz temperature, water vapour content/RH, wind speed and direction. In this study, the diurnal variation of ozone over the BoB has been examined and the major features are discussed below along with that of $\mathrm{NO}_{2}$. The diurnal patterns of ozone observed during the present cruise can be broadly put into three categories: (1) noon/afternoon decrease with nighttime high (2) afternoon and nighttime low and (3) daytime high and nighttime low. Similar patterns were observed during the pre-monsoon period (Nair et al., 2011). The major feature in each category is discussed below.

\subsubsection{Noon/afternoon decrease with nighttime high}

On majority of days, the ozone mixing ratio showed decrease during noon/afternoon followed by an increase and remaining high until the next day morning hours. The diurnal pattern of this type is shown in Fig. 10a along with the corresponding variation in temperature, $\mathrm{NO}_{2}$ and water vapour content $\left(\rho_{\mathrm{v}}\right)$. From the measured values of RH and $T$, onboard the ship, the water vapour content is estimated using the empirical relation given by Kneizys et al. (1980) and discussed by David and Nair (2011).
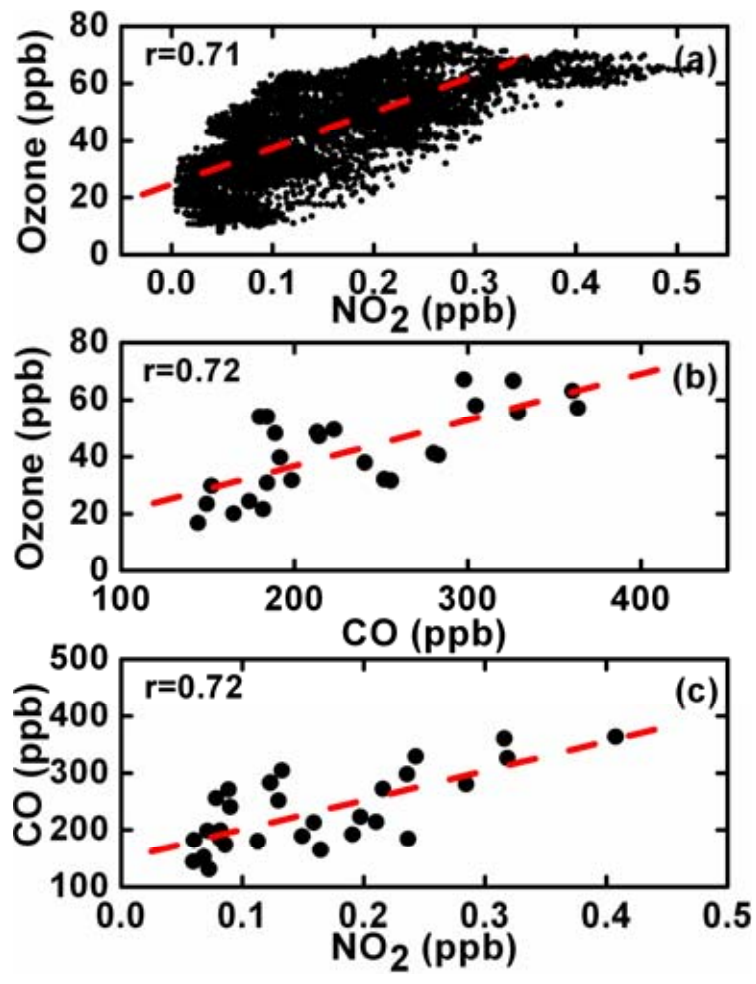

Fig. 9. Scatter plot of ozone with (a) $\mathrm{NO}_{2}$ and (b) $\mathrm{CO}$ and (c) scatter plot of $\mathrm{CO}$ and $\mathrm{NO}_{2}$.

The noontime low can be partly attributed to the vertical mixing of ozone to higher levels that lead to dilution at the surface level when convective activities are strong. At night, vertical mixing of free tropospheric air with the marine boundary layer (MBL) lead to the higher ozone mixing ratio (Bremaud et al., 1998). Similar diurnal variation has been observed in the Pacific, Indian Ocean region and over the BoB earlier (Johnson et al., 1990; Nair et al., 2011). From Fig. 10a, it is seen that there is no significant increase/decrease in $\mathrm{NO}_{2}$ when minimum is obtained in ozone. Thus it is clear that photochemistry, which involves $\mathrm{NO}_{2}$, does not play a major role in producing the above diurnal pattern of ozone. In fact, the $\mathrm{NO}_{2}$ mixing ratio itself is $<100 \mathrm{ppt}$ (that of $\mathrm{NO}$ being still low, of the order of $50 \mathrm{ppt}$ ). Hence, the ozone photolysis and subsequent production of $\mathrm{OH} / \mathrm{HO}_{2} \mathrm{rad}-$ ical (from water vapour) leads to destruction of ozone during daytime. On these days, it is observed that the noontime decrease in ozone is associated with an increase in $\rho_{\mathrm{v}}$ as can be seen from Fig. 10a.

\subsubsection{Afternoon and nighttime low}

On three days (8, 17 and 24 January) (Fig. 10b), it was seen that the ozone mixing ratio which remained high during the morning hours decreased during noon/afternoon hours and remained low until the next day morning. On these days, $\mathrm{NO}_{2}$ was relatively high till noontime and decreased 

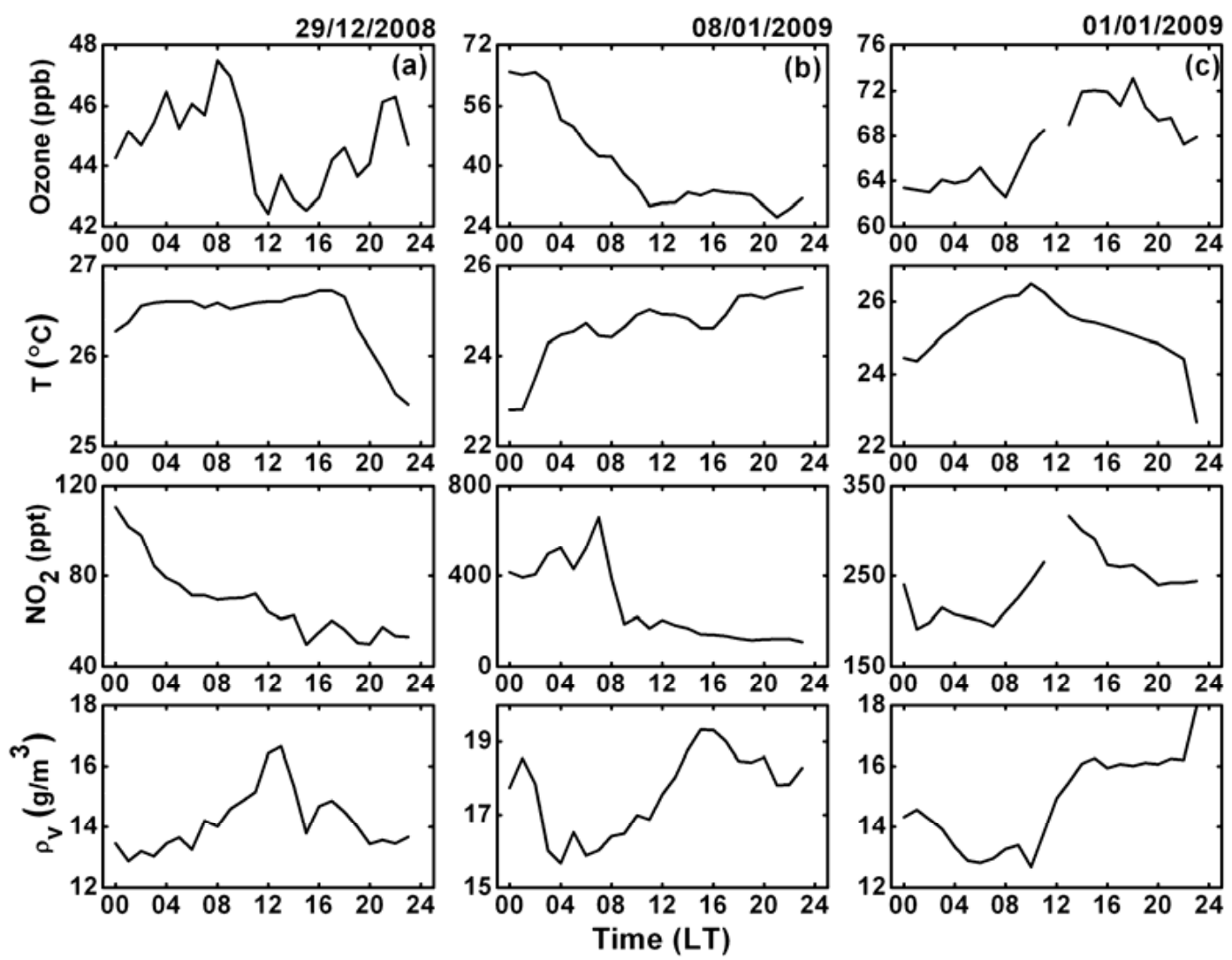

Fig. 10. Typical diurnal variations of ozone along with that of temperature, $\mathrm{NO}_{2}$ and water vapour content $\left(\rho_{\mathrm{V}}\right)$ for three days. The time is in Local Time (LT).

afterwards. There was no indication of active photochemistry as seen from the variation of temperature and $\mathrm{NO}_{2}$. But the afternoon decrease in ozone was linked with an increase in the water vapour content (Fig. 10b), as discussed in the above case. It is also noted that the temperature and water vapour content were not anti-correlated as observed over many continental sites.

\subsubsection{Daytime high and nighttime low}

In addition to this, on 1 January, when the ship was near to the coast (Fig. 10c), the diurnal pattern of ozone showed a daytime high and a nighttime low similar to that observed over several urban and inland sites (Naja and Lal, 2002; Nair et al., 2002; Jain et al., 2005; Beig et al., 2007). Increase in ozone was attributed to the photochemical reactions involving precursors, associated with the positive correlation with temperature and the precursor $\mathrm{NO}_{2}$ (Fig. 10c). On 10, 11 and 12 January also (when the ship was cruising in the southeast $\mathrm{BoB}$ ), ozone showed a daytime increase and evening decrease. However, neither temperature nor $\mathrm{NO}_{2}$ showed any correlation with ozone indicating $\mathrm{NO}_{2}$ controlled photochemical production. However, in this case also, the evening decrease is associated with an increase in $\rho_{\mathrm{v}}$.
The above analysis showed that over the marine region, water vapour content played a primary role in controlling the production/destruction of ozone and its precursors. Destruction of ozone and $\mathrm{NO}_{2}$ takes place through the reactions involving $\mathrm{OH}$ radical.

The effect of water vapour content and temperature on marine boundary layer ozone/ $\mathrm{NO}_{2}$ was further analyzed on daily basis along the cruise track. Figure 11a and b shows the scatter plot of surface ozone with temperature and $\rho_{\mathrm{v}}$, respectively. The straight lines represent the best-fit obtained through linear regression analysis. It can be clearly seen that ozone was anti-correlated with both temperature and $\rho_{\mathrm{v}}$ with the correlation coefficients being -0.75 and -0.88 , respectively. This clearly indicates the absence of active photochemical production of ozone over the marine environment.

\subsection{Box model simulations}

The Photochemical Box (zero-dimensional) model, NCAR Master Mechanism (NCAR-MM) (Madronich, 2006) was used to simulate the observed surface ozone and $\mathrm{NO}_{2}$ levels. The model simulates the chemical evolution of an air parcel, taking into account the detailed gas phase chemistry consisting of $\sim 5000$ reactions involving $\sim 2000$ species. 

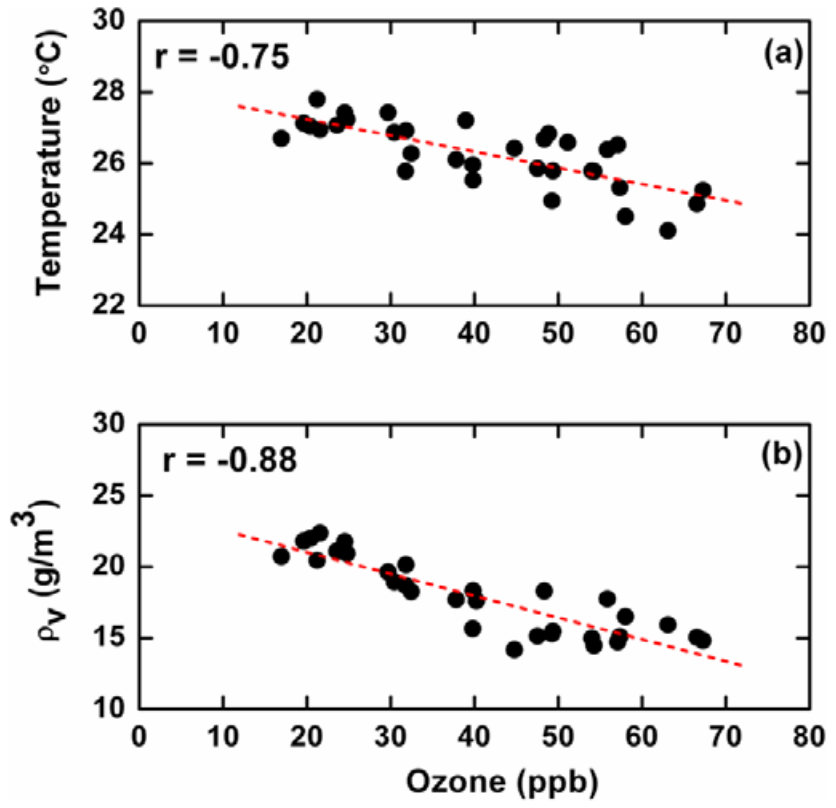

Fig. 11. Scatter plot of surface ozone with (a) temperature and (b) water vapour content $\left(\rho_{\mathrm{V}}\right)$.

The estimation of photolysis rate coefficients is done using the Tropospheric Ultraviolet Visible (TUV) radiative transfer model with a 4-stream discrete ordinate radiative transfer solver (Stamnes et al., 1988). Since it is known that the observations were carried out on a moving platform, the model has limitations in simulating the actual conditions. In the present analysis, the observed ozone and $\mathrm{NO}_{2}$ were simulated for two contrasting conditions (1) for the high ozone region of north/head BoB (as observed on 7 January 2009) and (2) low ozone region of south BoB (as observed on 24 January 2009). The measured meteorological conditions and aerosol parameters were used for the simulation. Satellite measured column ozone and $\mathrm{NO}_{2}$ values were used. The initial values of hydrocarbons were obtained by giving an enhancement of $\sim 30 \%$ to the average values for the north and south BoB regions, which were measured in the monsoon season by Sahu et al. (2006). For some of the species, initial conditions were generated by doing trial/sensitivity simulations. The values used for ozone, $\mathrm{NO}_{2}, \mathrm{NO}$ and $\mathrm{CO}$ are $10 \mathrm{ppb}, 6 \mathrm{ppb}, 1 \mathrm{ppb}$, and $700 \mathrm{ppb}$ respectively for the north/head BoB and $10 \mathrm{ppb}, 0.7 \mathrm{ppb}, 0.1 \mathrm{ppb}$ and $250 \mathrm{ppb}$ respectively for the south $\mathrm{BoB}$ simulations. Figure $12 \mathrm{a}$ and $\mathrm{b}$ shows the simulations of ozone and $\mathrm{NO}_{2}$ initialized with the above mentioned conditions along with the observed ozone and $\mathrm{NO}_{2}$ for the north and south $\mathrm{BoB}$, respectively. For north $\mathrm{BoB}$, after $48 \mathrm{~h}$ of chemical evolution, the model simulated ozone and $\mathrm{NO}_{2}$ levels are $\sim 65 \mathrm{ppb}$ and $0.26 \mathrm{ppb}$, respectively, which matches with the observed levels of $\sim 63 \mathrm{ppb}$ and $0.3 \mathrm{ppb}$, respectively. For southern BoB also, the model could simulate the observed levels of ozone and $\mathrm{NO}_{2}$ with
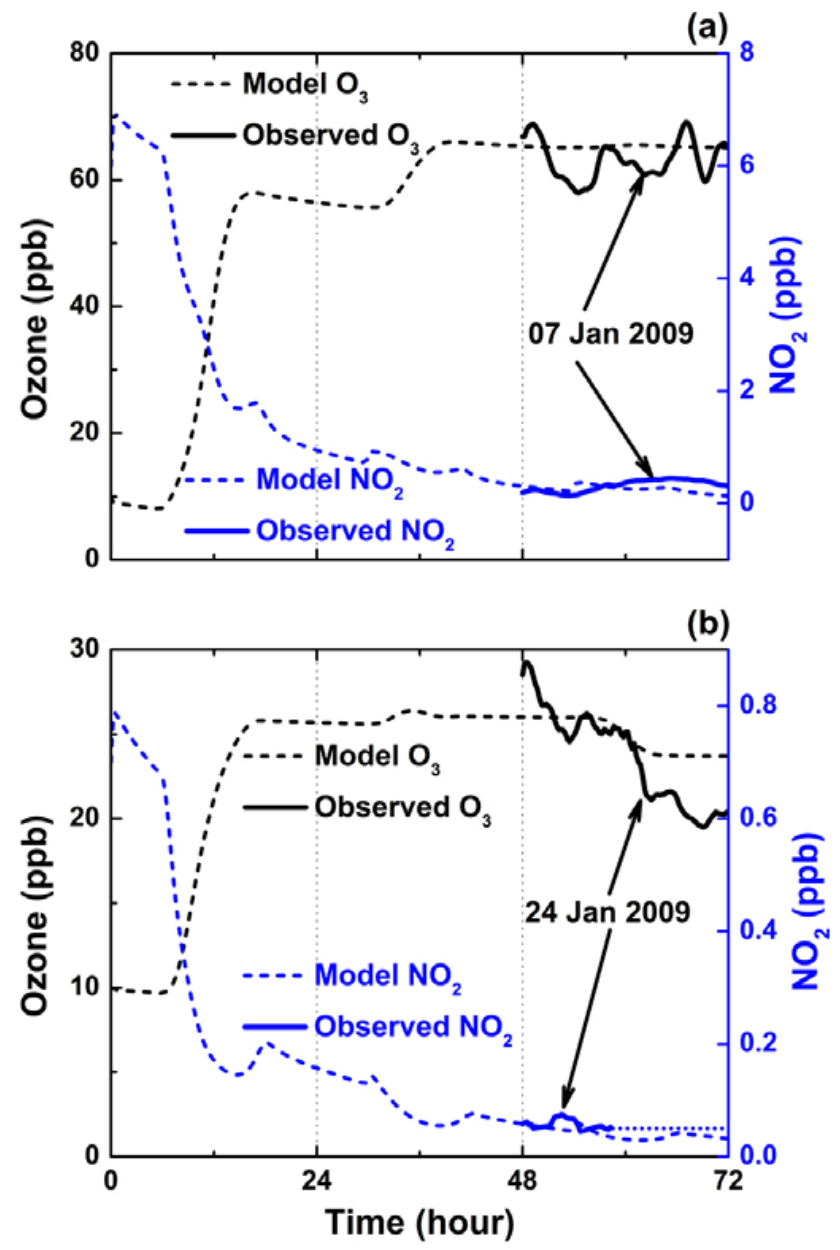

Fig. 12. The simulated ozone and $\mathrm{NO}_{2}$ along with the observed values for (a) 7 January 2009 (day with high ozone) and (b) 24 January 2009 (day with low ozone).

reasonable accuracy. While the simulated ozone and $\mathrm{NO}_{2}$ values are $25 \mathrm{ppb}$ and $0.04 \mathrm{ppb}$, respectively, the observed levels were $24 \mathrm{ppb}$ and $\sim 0.05-0.06 \mathrm{ppb}$, respectively. After $\sim 60 \mathrm{~h}$, observed $\mathrm{NO}_{2}$ values were below the detection limit of the instrument, which is shown by the dotted line. It is worth mentioning that model does not account for the transport and dynamics which play an important role in controlling the observed variations of various species. Also no additional emissions, dilution and heterogeneous processes were considered in the model. However, this model is capable of reproducing the broad features of the chemical species.

\subsection{Seasonal changes in ozone - pre-monsoon and win- ter period}

The present campaign provided information on the winter time characteristics of ozone over the BoB. The first ICARB campaign was conducted in the pre-monsoon/summer months (18 March-12 April 2006) with a large latitudinal 

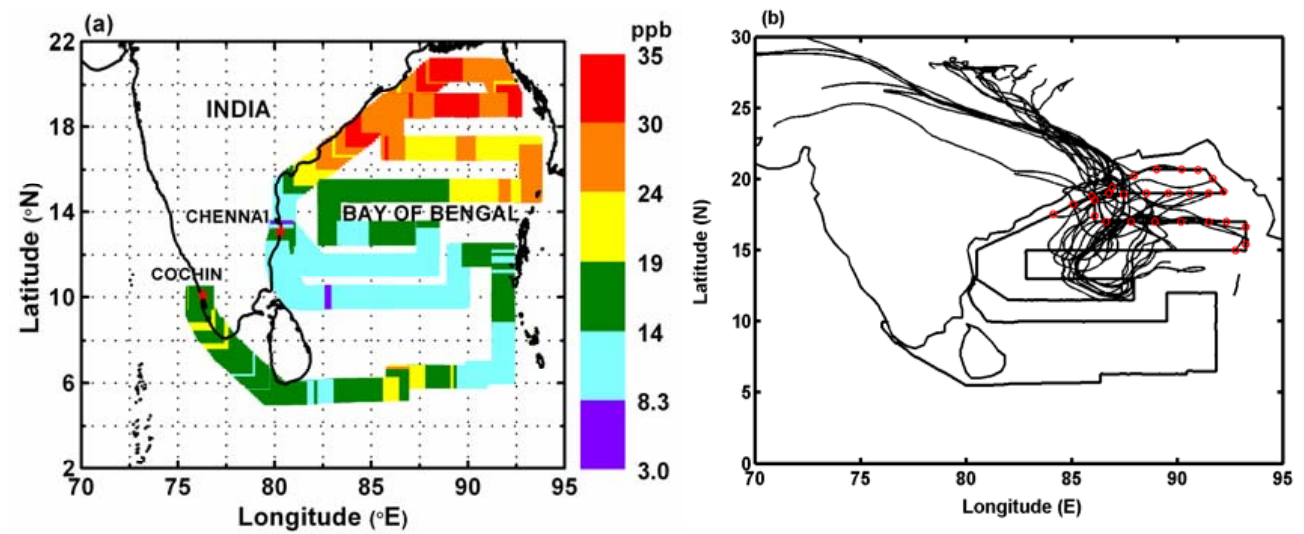

(c) Mean tropospheric ozone (ppbv)
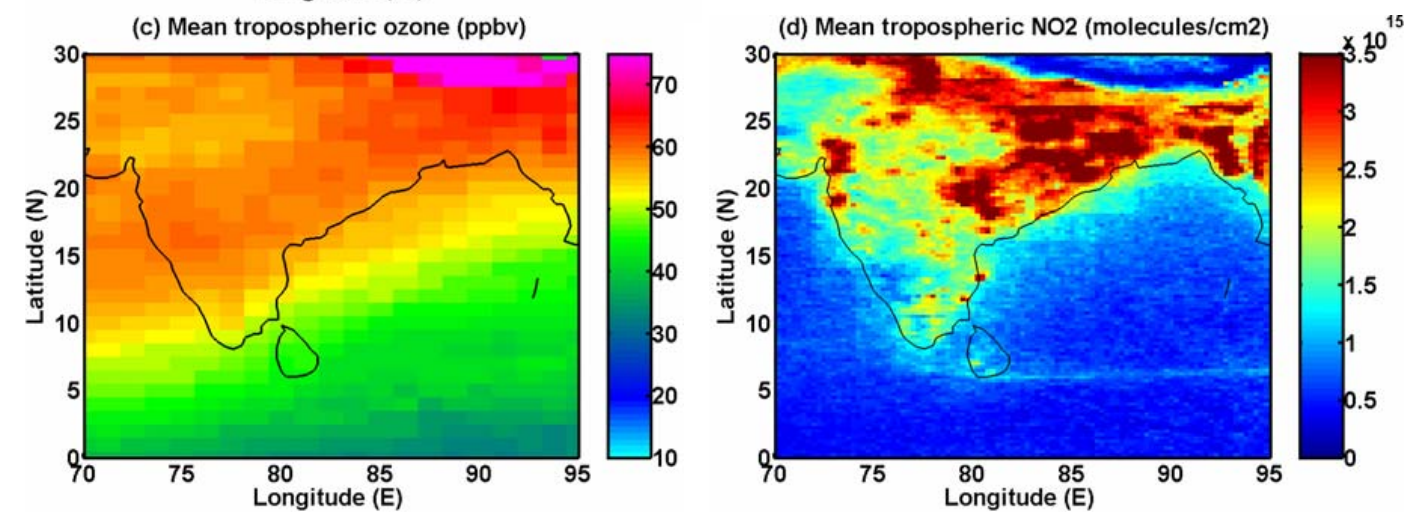

Fig. 13. (a) Spatial variation of near-surface ozone; (b) 7-day air mass back trajectory; (c) mean volume mixing ratio of tropospheric ozone and (d) tropospheric $\mathrm{NO}_{2}$ column for the pre-monsoon period.

$\left(5^{\circ}-22^{\circ} \mathrm{N}\right)$ and longitudinal $\left(76^{\circ}-93^{\circ} \mathrm{E}\right)$ coverage over the $\mathrm{BoB}$. These months represent the transitional period of the synoptic flow pattern over Asia and the adjoining oceanic region. The northeasterly weakens during March to May and the southwesterly start flowing by the end of May (Lawrence and Lelieveld, 2010). However, over the BoB this period depicts the outflow from the northern land mass (IGP) and mixing of air mass from the southern oceanic regions. During winter, the wind was northerly/northeasterly over the head $\mathrm{BoB}$ and mostly southeasterly over the southern regions. Near-surface ozone measurements were conducted with the UV photometric ozone analyzer during the premonsoon campaign also (Nair et al., 2011). Figure 13a shows the spatial variation of surface ozone along the cruise track as observed during the pre-monsoon period. Comparison of Figs. 13a and 3a clearly shows that irrespective of the season, high ozone mixing ratio existed over the head BoB. However, the ozone mixing ratio was higher $(61 \pm 7 \mathrm{ppb})$ in winter compared to that in the pre-monsoon period $(27 \pm 3 \mathrm{ppb})$ over the head $\mathrm{BoB}$ region. Over the mid-BoB, the mixing ratio was minimum during pre-monsoon ( $13 \pm 3 \mathrm{ppb}$ ) compared to the southern $\mathrm{BoB}(15 \pm 3 \mathrm{ppb})$. But in winter, in the southern BoB ozone mixing ratio was lower $(24 \pm 7 \mathrm{ppb})$ than in the mid-BoB ( $36 \pm 8 \mathrm{ppb})$. During the pre-monsoon months, the air mass back trajectories (Fig. 13b) originated and travelled over the north western and the central regions of the Indian subcontinent to reach the head BoB. The transport of ozone and/or precursors from the land mass led to enhanced levels of ozone over this region (Nair et al., 2011). During winter, the trajectories passed through IGP and Bangladesh where strong source regions of pollutants exist. The tropospheric ozone as well as $\mathrm{NO}_{2}$ also indicates this. In Fig. $13 \mathrm{c}$ and $\mathrm{d}$ are shown the mean volume mixing ratio of tropospheric ozone and tropospheric column $\mathrm{NO}_{2}$, respectively during the premonsoon months. An interesting feature observed from these figures is that the tropospheric ozone is higher during the premonsoon/summer (due to increased photochemical production) as compared to winter months. Moreover, the strong convective activity prevailing during pre-monsoon/summer, enables mixing of ozone and precursors to higher levels. On the other hand, in winter, convective activity and turbulent mixing are minimal thus leading to confinement of pollutants near to the surface and increasing their concentration level.

\subsection{Comparison with previous measurements}

Table 2 shows a comparison in the mean ozone mixing ratio during the different campaigns over the BoB. The spatial variation of ozone has been studied over the BoB during cruises in different seasons. The southern part (south of 
Table 2. A comparison in mean ozone mixing ratio during the different campaigns over the BoB.

\begin{tabular}{lcc}
\hline Cruise & Region & $\begin{array}{c}\text { Mean ozone } \\
\text { mixing ratio }\end{array}$ \\
\hline INDOEX 1999 & $<10^{\circ} \mathrm{N}$ & $22.4 \pm 1.5$ \\
BOBEX 2001 & $12^{\circ}-21^{\circ} \mathrm{N}, 80^{\circ}-89^{\circ} \mathrm{E}$ & $42.2 \pm 12.0$ \\
BOBPS 2002 & $7^{\circ}-20^{\circ} \mathrm{N}, 80^{\circ}-88^{\circ} \mathrm{E}$ & $27 \pm 6$ \\
BOB 2003 & $6^{\circ}-20^{\circ} \mathrm{N}, 75^{\circ}-90^{\circ} \mathrm{E}$ & $34 \pm 6$ \\
ICARB 2006 & $5^{\circ}-22^{\circ} \mathrm{N}, 80^{\circ}-93^{\circ} \mathrm{E}$ & $17.6 \pm 7.1$ \\
ICARB 2008-09 & $3.5^{\circ}-21^{\circ} \mathrm{N}, 76^{\circ}-98^{\circ} \mathrm{E}$ & $42.1 \pm 15.4$ \\
\hline
\end{tabular}

$\sim 10^{\circ} \mathrm{N}$ ) of BoB was studied during INDOEX 1999 (Mühle et al., 2002) in the February-March months. The BOBEX (Bay of Bengal Experiment) was conducted in the late winter period (18 February to 23 March 2001) which covered both the coastal and open oceanic region of $\mathrm{BoB}$ (Lal et al., 2006). During this period, the air mass flow was from India and southeast Asia to the measurement area (de Gouw et al., 2001). The BOBPS (Bay of Bengal Processes Studies) was conducted during the post-monsoon months (SeptemberOctober 2002) (Sahu et al., 2006). This campaign also covered the east coast of India and the mid-BoB region. In this study, the observed levels were attributed to emissions from India and Sri Lanka due to the summer monsoon circulation over this region. Another campaign was conducted from 1928 February 2003 when different types of air mass were identified depending on the source regions and transport pathways. Highest levels of pollutants were caused by the long range transport from the extratropical Northern Hemisphere (mostly from the Middle East) and it was moderate when the air mass was from the IGP regions (Lal et al., 2007). During the first ICARB conducted in pre-monsoon (Fig. 13a), the continental air mass/outflow from IGP caused enhanced ozone levels over the head $\mathrm{BoB}$ and the marine air mass brings in less ozone over to the southern BoB. Divergence of airflow results in reduced levels of ozone over the midBoB (Nair et al., 2011). In the present cruise, observation of ozone was made over the BoB in the winter period.

\section{Conclusion}

Measurements made over the marine boundary layer of Bay of Bengal during winter showed large variation in the mixing ratio of ozone and its precursor gases- $\mathrm{NO}_{2}$ and $\mathrm{CO}$. All these gases exhibited prominent high over the head and the southeast $\mathrm{BoB}$ with lower values in the southern $\mathrm{BoB}$ region. Analysis of airflow patterns and air mass back trajectories revealed that the spatial patterns were governed by transport from the adjoining land mass. While the high in the head BoB was due to advection from the IGP/Bangladesh, that in the southeast BoB was contributed by the South East
Asian region. Similarity in the spatial patterns of ozone and precursors pointed out that their source regions may be the same, but their relative contributions vary. Photochemical production involving $\mathrm{NO}_{2}$ does not play a major role in the production of ozone in the marine boundary layer of BoB. High water vapour content in the marine boundary layer acts as a sink for ozone. Most of the diurnal patterns showed high ozone mixing ratios in the morning hours followed by noon/afternoon decrease and night time increase. While the low ozone mixing ratio is associated with increase in water vapour content, the high is linked with low water vapour content as well as the mixing of ozone-rich free tropospheric air with that in the boundary layer. The high level of ozone measured over the head BoB and the low measured over the south $\mathrm{BoB}$ were simulated using the photochemical box model (NCAR-MM). The present measurements conducted during winter was compared with those during the pre-monsoon period and it was found that irrespective of the season, ozone was high over the head BoB, which is under the direct influence of continental/anthropogenic activities. Winter time mixing ratio of ozone is significantly higher than that during the pre-monsoon period.

Acknowledgements. The Dutch-Finnish built OMI is part of the NASA EOS Aura satellite payload. The OMI project is managed by NIVR and KNMI in the Netherlands. The $\mathrm{OMI} \mathrm{NO}_{2}$ data was provided by http://avdc.gsfc.nasa.gov/. The authors gratefully acknowledge D. Bala Subrahamanyam and N. V. P. Kiran Kumar for providing meteorological data recorded onboard ship. One of the authors L. M. David is ISRO Research Fellow during the period of this work.

Topical Editor P. M. Ruti thanks two anonymous referees for their help in evaluating this paper.

\section{References}

Asatar, G. I. and Nair, P. R.: Spatial distribution of near-surface CO over Bay of Bengal during winter: role of transport, J. Atmos. Solar Terr. Phys., 72, 1241-1250, 2010.

Baldy, S., Ancellet, G., Bessafi, M., Badar, A., and Luk, D. L. S.: Field observations of the vertical distribution of tropospheric ozone at the island of Reunion (southern tropics), J. Geophys. Res., 101, 23835-23849, 1996.

Beig, G., Gunthe, S., and Jadhav, D. B.: Simultaneous measurements of ozone and its precursors on a diurnal scale at a semiurban site in Pune, J. Atmos. Chem., 57, 239-253, 2007.

Bhugwant, C. and Bremaud, P.: Simultaneous measurement of black carbon, $\mathrm{PM} 10$, ozone and $\mathrm{NO}_{\mathrm{x}}$ variability at a locally polluted island in the southern tropics, J. Atmos. Chem., 39, 261280, 2001.

Bremaud, P. J., Taupin, F., Thompson, A. M., and Chaumerliac, N.: Ozone nighttime recovery in the marine boundary layer: Measurement and simulation of the ozone diurnal cycle at Reunion Island, J. Geophys. Res., 103, 3463-3473, 1998.

Browell, E. V., Fenn, M. A., Butler, C. F., Grant, W. B., Clayton, M. B., Fishman, J., Bachmeier, A. S., Anderson, B. E., Gregory, G. L., Fuelberg, H. E., Bradshaw, J. D., Sandholm, S. T., Blake, D. 
R., Heikes, B. G., Sachse, G. W., Singh, H. B., and Talbot, R. W.: Ozone and aerosol distributions and air mass characteristics over the South Atlantic basin during the burning season, J. Geophys. Res., 101, 24043-24068, 1996.

Carsey, T. P., Churchill, D. D., Farmer, M. L., Fischer, C. J., Pszenny, A. A., Ross, V. B., Saltzman, E. S., Young, M. S., and Bonsang, B.: Nitrogen oxides and ozone production in the North Atlantic marine boundary layer, J. Geophys. Res., 102, 1065310665, 1997.

Celarier, E. A., Brinksma, E. J., Gleason, J. F., Veefkind, J. P., Cede, A., Herman, J. R., Ionov, D., Goutail, F., Pommereau, J. P., Lambert, J. C., van Roozendael, M., Pinardi, G., Wittrock, F., Schönhardt, A., Richter, A., Ibrahim, O. W., Wagner, T., Bojkov, B., Mount, G., Spinei, E., Chen, C. M., Pongetti, T. J., Sander, S. P., Bucsela, E. J., Wenig, M. O., Swart, D. P. J., Volten, H., Kroon, M., and Levelt, P. F.: Validation of Ozone Monitoring Instrument nitrogen dioxide columns, J. Geophys. Res., 113, D15S15, doi:10.1029/2007JD008908, 2008.

Chand, D., Lal, S., and Naja, M.: Variations of ozone in the marine boundary layer over the Arabian Sea and the Indian Ocean during the 1998 and 1999 INDOEX campaigns, J. Geophys. Res., 108, 4190, doi:10.1029/2001JD001589, 2003.

Crutzen, P. J.: Photochemical reactions initiated by and influencing ozone in unpolluted tropospheric air, Tellus, 26, 47-57, 1974.

David, L. M. and Nair, P. R.: Diurnal and seasonal variability of surface ozone and $\mathrm{NO}_{\mathrm{x}}$ at a tropical coastal site: Association with mesoscale and synoptic meteorological conditions, J. Geophys. Res., 116, D10303, doi:10.1029/2010JD015076, 2011.

de Gouw, J. A., Warneke, C., Scheeren, H. A., van der Veen, C., Bolder, M., Scheele, M. P., Williams, J., Wong, S., Lange, L., Fischer, H., and Lelieveld, J.: Overview of the trace gas measurements on board the citation aircraft during the intensive field phase of INDOEX, J. Geophys. Res., 85, 28453-28467, 2001.

de Laat, A. T. J. and Lelieveld, J.: Diurnal ozone cycle in the tropical and subtropical marine boundary layer, J. Geophys. Res., 105, 11547-11559, 2000.

Draxler R. R. and Rolph, G. D.: HySPLIT (Hybrid Single Particle Lagrangian Integrated Trajectory) Model access via NOAA ARL READY website (http://www.arl.noaa.gov/ready/hysplit4.html), NOAA Air Resources Laboratory, Silver Spring, MD, 2003.

Fishman, J., Solomon, S., and Crutzen, P. J.: Observational and theoretical evidence in support of a significant in-situ photochemical source of tropospheric ozone, Tellus, 31, 432-446, 1979.

Ganguly, N. D. and Tzanis, C.: Study of stratosphere-troposphere exchange events of ozone in India and Greece using ozonesonde ascents, Meteoro. Appl., in press, doi:10.1002/met.241, 2011.

Giglio, L., Descloitres, J., Justice, C. O., and Kaufman, Y. J.: An enhanced contextual fire detection algorithm for MODIS, Remote Sens. Environ., 87, 273-282, 2003.

Graedel, T. E. and Crutzen, P. J.: Atmospheric Change: An Earth System Perspective, W. H. Freeman, New York, 1992.

Intergovernmental Panel on Climate Change: Climate Change 2007: The Physical Science Basis, contribution of Working Group I to the Fourth Assessment Report of the Intergovernmental Panel on Climate Change, edited by: Solomon, S., Qin, D., Manning, M., Chen, Z., Marquis, M., Averyt, K. B., Tignor, M., and Miller, H. L., Cambridge Univ. Press, Cambridge, UK and New York, USA, 2007.

Jacob, D. J., Logan, J. A., and Murti, P. P.: Effect of rising Asian emissions on surface ozone in the United States, Geophys. Res. Lett., 26, 2175-2178, 1999.

Jain, S. L., Arya, B. C., Kumar, A., Ghude, S. D., and Kulkarni, P. S.: Observational study of surface ozone at New Delhi, India, Int. J. Remote Sens., 26, 3515-3524, 2005.

Johnson, J. E., Gammon, R. H., Larsen, J., Bates, T. S., Oltmans, S. J., and Farmer, J. C.: Ozone in the marine boundary layer over the Pacific and Indian Oceans: Latitudinal gradients and diurnal cycles, J. Geophys. Res., 95, 11847-11856, 1990.

Kar, J., Jones, D. B. A., Drummond, J. R., Attié, J. L., Liu, J., Zou, J., Nichitiu, F., Seymour, M. D., Edwards, D. P., Deeter, M. N., Gille, J. C., and Richter, A.: Measurement of low-altitude CO over the Indian subcontinent by MOPITT, J. Geophys. Res., 113, D16307, doi:10.1029/2007JD009362, 2008.

Kley, D., Crutzen, P. J., Smit, H. G., Vomal, H., Oltmans, S. J., Grassl, H., and Ramanathan, V.: Observations of near-zero ozone concentrations over the convective Pacific: Effects on air chemistry, Science, 274, 230-233, 1996.

Kneizys, F. X., Shettle, E. P., Gallery, W. O., Chetwynd Jr., J. H., Abreu, L. W., Selby, J. E. A., Fenn, R. W., and McClatchey, R. A.: Atmospheric transmittance/radiance: Computer code LOWTRAN 5, Environ. Res. Papers, 697, 217-219, 1980.

Lal, S. and Lawrence, M. G.: Elevated mixing ratios of surface ozone over the Arabian Sea, Geophys. Res. Lett., 28, 1487-1490, 2001.

Lal, S., Naja, M., and Subbaraya, B. H.: Seasonal variations in surface ozone and its precursors over an urban site in India, Atmos. Environ., 34, 2713-2724, 2000.

Lal, S., Chand, D., Sahu, L. K., Venkataramani, S., Brasseur, G., and Schultz, M. G.: High levels of ozone and related gases over the Bay of Bengal during winter and early spring of 2001, Atmos. Environ., 40, 1633-1644, 2006.

Lal, S., Sahu, L. K., and Venkataramani, S.: Impact of transport from the surrounding continental regions on the distributions of ozone and related trace gases over the Bay of Bengal during February 2003, J. Geophys. Res., 112, D14302, doi:10.1029/2006JD008023, 2007.

Lawrence, M. G. and Lelieveld, J.: Atmospheric pollutant outflow from southern Asia: a review, Atmos. Chem. Phys., 10, 1101711096, doi:10.5194/acp-10-11017-2010, 2010.

Lelieveld, J., van Aardenne, J., Fischer, H., de Reus, M., Williams, J., and Winkler, P.: Increasing ozone over the Atlantic Ocean, Science, 304, 1483-1487, 2004.

Madronich, S.: Chemical evolution of gaseous air pollutants downwind of tropical megacities: Mexico city case study, Atmos. Environ., 40, 6012-6018, doi:10.1016/j.atmosenv.2005.08.047, 2006.

McConnell, J. C. and McElroy, M. B.: Odd nitrogen in the atmosphere, J. Atmos. Sci., 30, 1465-1480, 1973.

Monks, P. S., Carpenter, L. J., Penkett, S. A., Ayers, G. P., Gillett, R. W., Galbally, I. E., and Meyer, C. P.: Fundamental ozone photochemistry in the remote marine boundary layer: The SOAPEX experiment, measurement and theory, Atmos. Environ., 32, 3647-3664, 1998.

Mühle, J., Zahn, A., Brenninkmeijer, C. A. M., Gros, V., and Crutzen, P. J.: Air mass classification during the INDOEX R/V Ronald Brown cruise using measurements of nonmethane hydrocarbons, $\mathrm{CH}_{4}, \mathrm{CO}_{2}, \mathrm{CO},{ }^{14} \mathrm{CO}$, and $\delta^{18} \mathrm{O}(\mathrm{CO})$, J. Geophys. Res., 107, 8021, doi:10.1029/2001Jd000730, 2002. 
Nair, P. R., Chand, D., Lal, S., Modh, K. S., Naja, M., Parameswaran, K., Ravindran, S., and Venkataramani, S.: Temporal variations in surface ozone at Thumba $\left(8.6^{\circ} \mathrm{N}, 77^{\circ} \mathrm{E}\right)-$ a tropical coastal site in India, Atmos. Environ., 36, 603-610, 2002.

Nair, P. R., David, L. M., Girach, I. A., and George, S. K.: Ozone in the marine boundary layer of Bay of Bengal during post-winter period: Spatial pattern and role of meteorology, Atmos. Environ., 45, 4671-4681, 2011.

Naja, M. and Lal, S.: Surface ozone and precursor gases at Gadanki $\left(13.5^{\circ} \mathrm{N}, 79.2^{\circ} \mathrm{E}\right)$, a tropical rural site in India, J. Geophys. Res., 107, 4197, doi:10.1029/2001JD000357, 2002.

Platt, U. F., Winer, A. M., Biermann, H. W., Atkinson, R., and Pitts Jr., J. N.: Measurement of nitrate radical concentrations in continental air, Environ. Sci. Technol., 18, 365-369, 1984.

Prasad, A. K., Singh, R. P., and Kafatos, M.: Influence of coal based thermal power plants on aerosol optical properties in the Indo-Gangetic basin, Geophys. Res. Lett., 33, L05805, doi:10.1029/2005GL023801, 2006.

Ramanathan, V. and Dickinson, R. E.: The role of stratospheric ozone in the zonal and seasonal radiative energy balance of the Earth-troposphere system, J. Atmos. Chem., 36, 1084-1104, 1979.

Rhoads, K. P., Kelley, P., Dickerson, R. R., Carsey, T. P., Farmer, M., Savoie, D. L., Prospero, J. M., and Crutzen, P. J.: The composition of the troposphere over the Indian Ocean during the monsoonal transition, J. Geophys. Res., 102, 18981-18995, 1997.

Sahu, L. K., Lal, S., and Venkataramani, S.: Distributions of $\mathrm{O}_{3}$, $\mathrm{CO}$ and hydrocarbons over the Bay of Bengal: A study to assess the role of transport from southern India and marine regions during September-October 2002, Atmos. Environ., 40, 4633-4645, 2006.

Singh, H. B., Herlth, D., Kolyer, R., Salas, L., Bradshaw, J. D., Sandholm, S. T., Davis, D. D., Crawford, J., Kondo, Y., Koike, M., Talbot, R., Gregory, G. L., Sachse, G. W., Browell, E., Blake, D. R., Rowland, F. S., Newell, R., Merrill, J., Heikes, B., Liu, S. C., Crutzen, P. J., and Kanakidou, M.: Reactive nitrogen and ozone over the western Pacific: Distribution, partitioning, and sources, J. Geophys. Res., 101, 1793-1808, 1996a.
Singh, H. B., Gregory, G. L., Anderson, B., Browell, E., Sachse, G. W., Davis, D. D., Crawford, J., Bradshaw, J. D., Talbot, R., Blake, D. R., Thornton, D., Newell, R., and Merrill, J.: Low ozone in the marine boundary layer of the tropical Pacific Ocean: Photochemical loss, chlorine atoms, and entrainment, Singh, J. Geophys. Res., 101, 1907-1917, 1996 b.

Smith S. R., Bourassa, M. A., and Sharp, R. J.: Establishing more truth in true winds, J. Atmos. Oceanic Technol., 16, 939-952, 1999.

Sprenger, M., Wernli, H., and Bourqui, M.: StratosphereTroposphere exchange and its relation to potential vorticity streamers and cutoffs near the extratropical tropopause, J. Atmos. Sci., 64, 1587-1604, 2007.

Stamnes, K., Tsay, S., Wiscombe, W. J., and Jayaweera, K.: Numerically stable algorithm for discrete-ordinate-method radiative transfer in multiple scattering and emitting layered media, Appl. Optics, 27, 2502-2509, 1988.

Thompson, A. M., Johnson, J. E., Torres, A. L., Bates, T. S., Kelly, K. C., Atlas, E., Greenberg, J. P., Donahue, N. M., Yvon, S. A., Saltzman, E. S., Heikes, B. G., Mosher, B. W., Shashkov, A. A., and Yegorov, V. I.: Ozone observations and a model of marine boundary layer photochemistry during SAGA 3, J. Geophys. Res., 98, 16955-16968, 1993.

Tonnesen, G. S. and Dennis, R. L.: Analysis of radical propagation efficiency to assess ozone sensitivity to hydrocarbons and $\mathrm{NO}_{\mathrm{x}}$ 2. Long-lived species as indicators of ozone concentration sensitivity, J. Geophys. Res., 105, 9227-9241, 2000.

Ziemke, J. R., Chandra, S., Duncan, B. N., Froidevaux, L., Bhartia, P. K., Levelt, P. F., and Waters, J. W.: Tropospheric ozone determined from AURA OMI and MLS: Evaluation of measurements and comparison with the Global Modeling Initiative's Chemical Transport Model, J. Geophys. Res., 111, D19303, doi:10.1029/2006JD007089, 2006.

Ziemke, J. R., Chandra, S., Duncan, B. N., Schoeberl, M. R., Torres, O., Damon, M. R., and Bhartia, P. K.: Recent biomass burning in the tropics and related changes in tropospheric ozone, J. Geophys. Res., 36, L15819, doi:10.1029/2009GL039303, 2009. 